\title{
The Impact and Effectiveness of Entrepreneurship Policy
}

Link to publication record in Manchester Research Explorer

\section{Citation for published version (APA):}

Ramlogan, R., \& Rigby, J. (2012). The Impact and Effectiveness of Entrepreneurship Policy. (NESTA

Compendium). Manchester Institute of Innovation Research.

\section{Citing this paper}

Please note that where the full-text provided on Manchester Research Explorer is the Author Accepted Manuscript or Proof version this may differ from the final Published version. If citing, it is advised that you check and use the publisher's definitive version.

\section{General rights}

Copyright and moral rights for the publications made accessible in the Research Explorer are retained by the authors and/or other copyright owners and it is a condition of accessing publications that users recognise and abide by the legal requirements associated with these rights.

\section{Takedown policy}

If you believe that this document breaches copyright please refer to the University of Manchester's Takedown Procedures [http://man.ac.uk/04Y6Bo] or contact uml.scholarlycommunications@manchester.ac.uk providing relevant details, so we can investigate your claim.

\section{OPEN ACCESS}




\section{The Impact and Effectiveness of Entrepreneurship Policy}

Compendium of Evidence on the Effectiveness of Innovation Policy Intervention 


\section{Table of Contents}

List of Tables. 3

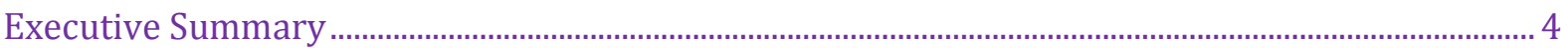

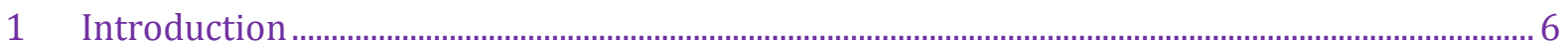

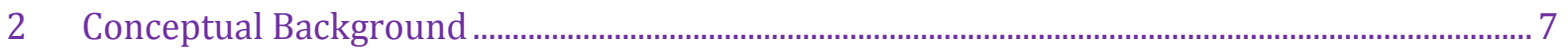

$2.1 \quad$ Entrepreneurialism: Characteristics......................................................................................... 7

2.1.1 The Entrepreneurial Nexus .................................................................................................... 9

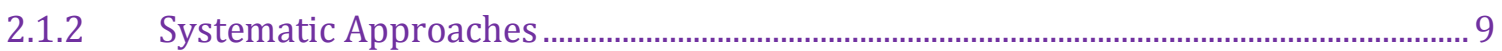

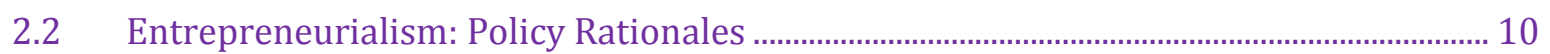

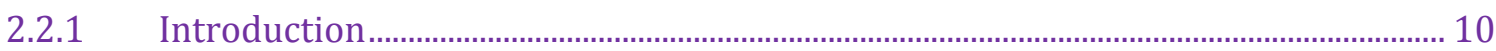

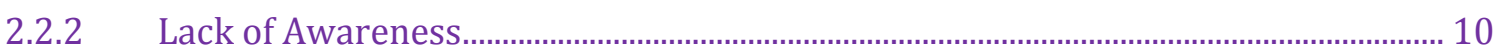

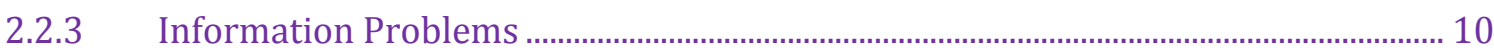

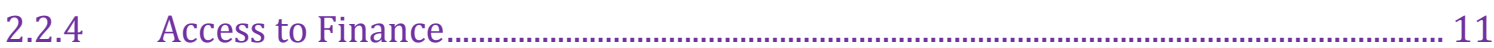

2.2.5 The Positive Externalities of Investment in R\&D and Innovation............................... 11

2.2.6 When there is doubt over market failure: the case of incubators ............................... 11

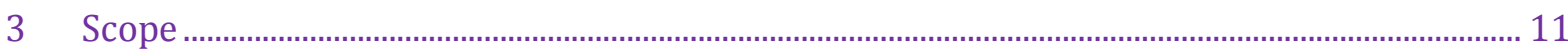

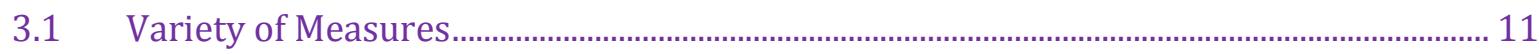

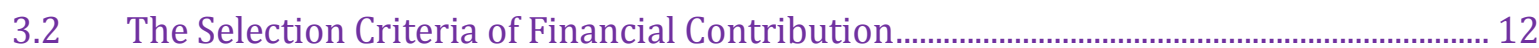

3.3 A Framework for the Presentation of Findings …………......................................................... 12

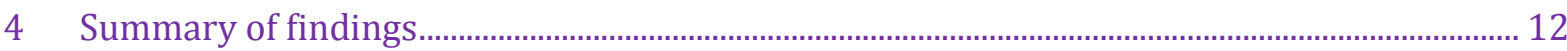

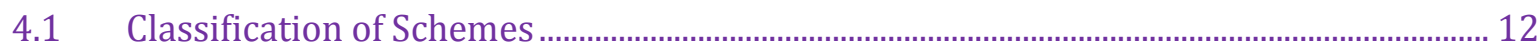

4.2 Schemes to Promote Cultural and Behavioural Change ........................................................... 13

4.3 Schemes to Provide Information ....................................................................................................... 15

4.3.1 Schemes to Provide Advice of a Standardized Form .................................................... 15

4.3.2 Schemes to Provide More Specific and Situational Advice.............................................. 20

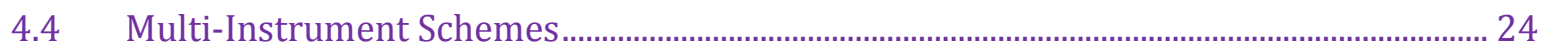

4.4.1 Schemes Combining Activities in Time................................................................................. 24

4.4.2 Schemes Combining Measures at a Location - Incubators .............................................. 28

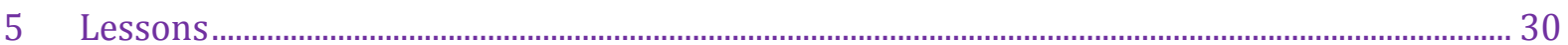

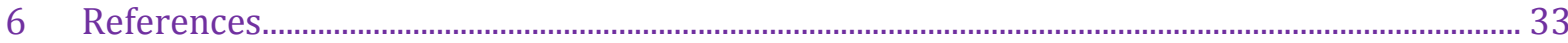

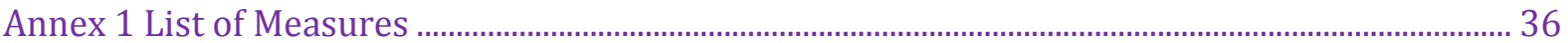




\section{List of Tables}

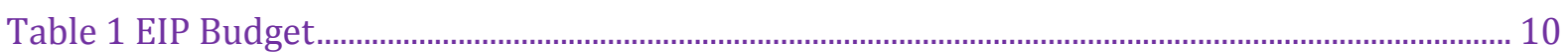

Table 2 Coaching: UK Approach East Midlands Development Agency, 2005_.................................... 22

Table 3 Coaching and Mentoring and Consultancy: East Midlands Development Agency 2005 . 23 


\section{Executive Summary}

Entrepreneurial ability is widely regarded as key factor for success in business and consequently innovation policy has been placing greater focus upon the entrepreneur, his skills and values, a development that has been termed by some the entrepreneurial turn.

This report examines publicly supported policies for entrepreneurship development. Entrepreneurship policies are directed to encouraging socially and economically productive activities by individuals acting independently in business. Their principal objective is to increase a level of entrepreneurial activity which is considered to be below the social optimum. Policies may be implemented directly to address entrepreneurs' needs e.g. business advice programmes or through broadcast methods such as education policy.

Entrepreneurship policy and SME policy both aim at causing two different kinds of effects in the economy. Both seek to improve the performance of economic actors (entrepreneurship policy is focused on the key actors in the business, the entrepreneur, while SME policy seeks to increase the competitiveness of the firm) and both seek to increase the number of economic actors, (entrepreneurship hoping to increase the level of supply of entrepreneurs, while SME policy hopes to increase the number of competitive firms).

In regard then to these two areas for entrepreneurship policy, we have attempted to locate and focus on evaluations that reported on additionality / net effect or that use methods of causal inference to determine the effectiveness and impacts of policy. Such studies tended to be found in the academic literature rather than amongst the reports on the performance of government schemes (that are publicly available).

We have examined the literature and it covers schemes that have been evaluated around a decade ago. Generally we find that recent policy initiatives in this area have not been evaluated. The policies and programmes that have emerged very recently have yet to be examined in detail.

In regard to policies and programmes seeking to effect cultural and behavioural impacts, we believe that the literature can teach a number of lessons. Programmes that seek to increase awareness of entrepreneurship as a career choice can be seen within the area of education policy. However the growing interest in entrepreneurial education has not been matched by sound evaluation evidence. Thus not only have the evaluations undertaken varied greatly, the majority of these studies appear limited in that they fail to include a pre-test post-test method, and few employ control groups or have a longitudinal dimension.

The studies we have uncovered have attempted to address one or more of these concerns and to understand whether or not entrepreneurship education causes individuals to change their intentions to become an entrepreneur. The effect of these schemes appears to be different at different points in of the education system: at school level, there is a negative and significant effect; at the college level the effect is low; at the university level, the effect is positive.

The evaluations noted an important effect on intentions, what we call a sorting effect, by which those who may be unsure about whether they wish to follow an entrepreneurial path will have their minds made up for them, often resulting in a decision not to become an entrepreneur. It almost goes without saying that these schemes which are aimed at cultural and behavioural 
change are not designed in the short term to impact upon production or efficiency of economic enterprises.

Schemes to provide information and advice of a standardized form are closest in form to those which are addressed at the firm, rather than the entrepreneur. We note within our review two different forms of support. There is a form of support providing advice and information to early stage firms, and a form of support to nascent firms or pre-firms (pre start-up) where the recipient is the entrepreneur or would-be entrepreneur. Schemes of the former type are assessed by reference to the conventional economic impact categories, sales, employment and firm survival. Schemes of the latter type are assessed by reference to the outcomes for the recipient of the support, usually employment status (unemployed, employed (as an entrepreneur)) and income.

Schemes of the former type of scheme are more homogenous in what they provide, while the latter kind is quite diverse and examples are difficult to compare one against another. The former type of scheme, of which the Business Link scheme and the Swedish Innovation Centre are examples, show mixed results. Overall, some schemes find positive impacts in terms of sales, employment and survival while in others impacts were statistically insignificant. The schemes offering support to pre start-up entrepreneurs again varied in outcome. In the short term, all schemes increased employment; however, in the longer term, the US scheme, GATE for example, does not show persistence of employment effects at 5 years.

More specific and situational advice schemes provision is a further sub-category of schemes that seek to address the market failure for advice. The vast majority of programmes of this kind are targeted at those who have elected to run their own business. However, we have found examples of schemes (Active Labour Market Policy Schemes) that target the unemployed - what could be called reluctant entrepreneurs. This scheme is really a combined scheme in that it provides both general training and more specific advice for the "would be" entrepreneur. Such schemes combine both general and specific help to the unemployed. Some minor impacts are noted but the outcomes that have been observed are not a strong endorsement for this kind of scheme.

Coaching schemes are difficult to assess for impact. Those schemes providing assistance to new entrepreneurs running their own business are popular with those who receive the coaching but there is a lack of studies that consider the counterfactual case. It is our belief that as more of these schemes are put into operation, and there is an expectation that they will be, more evaluation will take place. This may reveal the factors that affect success. Incubators also are problematic to assess as the evaluations of them deal with a great variety of schemes few of which are comparable.

While we have found a trend towards entrepreneurial support, we have found no studies that follow up explicitly on the contrast between specific help and more general or operational support, in effect a comparison of two different forms of government assistance. It is a moot point therefore whether these schemes that do have different objectives should be subject to comparison. 


\section{Introduction}

Entrepreneurial ability is widely regarded as key factor for success in business. The entrepreneur is the key mythic actor in the Schumpeterian account of the economic system and entrepreneurship is widely taught in business schools and within companies. Increasingly we see entrepreneurship instruction offered in schools to young children, in general university and college courses and even more widely than that. Some writers have noted that innovation policy is moving its emphasis away from the support of SMEs towards the support of entrepreneurship (Henrekson and Stenkula, 2009), a development that Cox and Rigby have termed "the entrepreneurial turn" (Cox and Rigby, 2012).

The study of initiatives to promote entrepreneurship generally raises interesting issues of public policy that might be regarded as technical in scope, and these we aim to deal with at some length in this paper where they are supported by a body of evidence from programme and policy evaluation. But we feel that we should note briefly a related and growing body of work covering entrepreneurship policy that is achieving public prominence. Entrepreneurship policy, by virtue of being a policy closely associated with a class of social and economic actors, is also quite unmistakeably a political matter. Entrepreneurialism is political creed in a number of countries but no more so than in the United States where a number of writers have extolled the culture of the United States as being more suited to entrepreneurialism than any other. In addition to cultural and social explanations for the origins of and value of entrepreneurialism there is a body of work emerging with the social and psychological sciences that investigates and in a number of cases demonstrates a strong link between entrepreneurial behaviour and genetics (Eckhardt et al., 2006; Nicolaou et al., 2008; Nicolaou and Shane, 2009; Nicolaou et al., 2009; Shane et al., 2010). Nevertheless, there are some who believe that entrepreneurship cannot be taught, that the desire to be entrepreneurial cannot be inculcated because it is "genetic" and that public resources that are allocated to such a task are a waste of money (Shane, 2009). This research we mention but not investigate as policy and programmes have yet to respond to incorporate its insights. We should note however that the UK approach may be making the assumption ${ }^{1}$ - we call the "selectivity of entrepreneurship" - that the firms that will succeed in becoming high growth are a minority, around 6\% (NESTA, 2009a; NESTA, 2009c).

This report therefore examines publicly supported policies for entrepreneurship development. The literature often and mistakenly equates entrepreneurship policy and SME policy but as a number of authors (e.g. Storey, 2005) indicate, there is a substantive difference. Whereas SME policies are directed to existing businesses or enterprises, and seek to provide advice and information to help with problems that are firm related (e.g. compliance with regulations, reporting requirements), entrepreneurship policies are directed towards individuals. These are individuals who are either considering, are about to, may wish to consider, or have recently started a new business.

Entrepreneurship policies are therefore directed to encouraging socially and economically productive activities by individuals acting independently in business (Henrekson and Stenkula, 2009). Their principal objective is the increase the level of entrepreneurial activity which is considered to be below the social optimum. Policies may be implemented directly to address entrepreneurs' needs e.g. business advice programmes or through the broader macroeconomic

\footnotetext{
${ }^{1}$ Based on work originally by Birch and reviewed, for the UK by NESTA (2009b).
} 
policy frameworks e.g. education policy. Many innovation policies can have a spatial dimension in that they may be provided in a particular location, for example, in a business incubator, in a science park, in a cluster, or in a region. As entrepreneurship policies are focused on the entrepreneur, we have included a brief survey of incubators in our review because at this spatial level, i.e. within incubators, support is generally provided to entrepreneurs and early stages businesses, while at larger scales, the target of support is more likely to be the firm itself rather than the entrepreneur. Our view here is that the incubator is not a distinct form of business support but a mainly locational principle for the delivery of specific activities ${ }^{2}$, including entrepreneurship skills, coaching, and access to other similar firms. Because incubators are highly diverse in the type and balance of the measures they provide, are different also in their location, and have the prospect of many interactions between their constituent activities, the method of meta-analysis / systematic review cannot be realistically applied to a comparative study of the evaluations of incubators. Our review of reports on incubators therefore discusses the most recent literature on incubators and the important general themes emerging. Depending on the level of resource support, entrepreneurial policies can be classified as being hard or soft (Storey, 2005). Hard policies usually provide assistance in the form of finance (loans and grants) while soft measures include counselling activities to entrepreneurs before business start-up, counselling at the start-up phase, facilitating financial assistance, enhancing technology and access to technology and improving access to physical infrastructure, or advice after the start.

Entrepreneurship policy and SME policy both aim at causing two different kinds of effects in the economy. Both seek to improve the performance of economic actors (entrepreneurship policy is focused on the key actors in the business, the entrepreneur, while SME policy seeks to increase the competitiveness of the firm) and both seek to increase the number of economic actors, (entrepreneurship hoping to increase the level of supply of entrepreneurs, while SME policy hopes to increase the number of competitive firms).

\section{Conceptual Background}

\subsection{Entrepreneurialism: Characteristics}

The literature sees entrepreneurship as comprising a range of personal characteristics, which we suggest can be considered to form two general categories: a) a value or attitude system of cultural values; and b) a set of skills which we suggest are instrumental in the realization of a value system. The value system is broadly a set of beliefs about ends, namely that the results of entrepreneurship, wealth creation, personal interest, self-realization through business and capital accumulation are the personal priority of an individual. Weber's famous study 1905 (Weber, 1905) is one of the best known but by no means the last to explore inter alia the relationship between belief systems and occupational success. By contrast, the entrepreneurial skill set comprises those aptitudes that give the entrepreneur the means of realizing the ends of the entrepreneur. The relation between ends and means is evidently problematic, given the circularity in both directions in determining the meaning of the terms, viz. entrepreneurs are

${ }^{2}$ Among the many sources of ambiguity in incubator research is debates about whether an incubator is a distinctive organisational form or a more general entrepreneurial environment and whether or not to include in any analysis virtual incubators that offer support business services to incubatees not co-located in the same physical space (incubator building) (Dee et al., 2012). 
people who have entrepreneurial skills on the one hand while entrepreneurial skills are those possessed by entrepreneurs on the other.

Our view of a vast literature on the broad issue of what entrepreneurs do and how such a field should be defined is that within the management and entrepreneurship literature on entrepreneurship there is a general agreement that entrepreneurship is concerned with instrumental action and less with values and ends. This view is in our opinion founded on the Austrian view of human action best exemplified by the work of Von Mises where ends and values of human action are assumed subjective and "input" to the calculating faculty of human rationality. How such rationality unfolds within markets and under conditions of scarcity is the Austrian orientation to the study of economics. It is not surprising therefore that this framework for the study of economics places the entrepreneur centre stage, and no more so than in the work of Schumpeter. This instrumental and action oriented approach underpins current work on entrepreneurship. As Shane notes in the Academy of Management Review "entrepreneurship ..[is].. the identification, evaluation and exploitation of opportunities" (Shane, 2012: 12). Furthermore, as Shane and Venkataraman (2000), entrepreneurship is distinct from the study of the firm ${ }^{3}$ including firm formation, a distinction that is important for policy.

While there is a strong assumption that entrepreneurship is therefore focused upon action, within the wider literature on entrepreneurship there is an awareness of and willingness to go beyond the one-dimensional concept of entrepreneurship qua rationality towards richer models that incorporate a variety of characteristics that affect entrepreneurial behaviour and its outcomes. Of note for policy makers and designers of support for entrepreneurship is a truly vast range of work on entrepreneurial characteristics, what might be called dimensions to entrepreneurial behaviour, and the link outcomes of many kinds, and some degree, a focus upon learning by experience and that, to paraphrase Goethe ${ }^{4}$, to achieve success as an entrepreneur, knowing is not enough, one must apply one's knowledge and experience the role by performing it.

We have reviewed some of this work and believe that a number of contributions are helpful in understanding where scope for policy action may exist: on entrepreneurial orientation (EO) (Dess et al., 2011); goal seeking by entrepreneurs (Ardichvili et al., 2003), the social contexts of entrepreneurship, and broader links to labour, taxation and other polices (Henrekson and Stenkula, 2009); on skills development, the OECD review (OECD, 2010) provides a framework that argues for a unique set of (convergent) skills that involve analysing and making use of and adapting new information to combine with existing information: "Entrepreneurship specific skills for creating and running new business ventures and innovative projects in existing firms, such as risk assessment and warranting, strategic thinking, self-confidence, the ability to make the best of personal networks, motivating others to achieve a common goal, co-operation for success, and the ability to deal with other challenges and requirements met by entrepreneurs" (OECD, 2010: 166).

3 The study of entrepreneurialism thus conceived denotes a field with unique characteristics - a knowledge domain to be studied in its own right with its own methods.

${ }^{4}$ Wilhelm Meister's Journeyman Years. 


\subsubsection{The Entrepreneurial Nexus}

While a large body of core of research centres on the entrepreneur as a key economic actor therefore, there has been a tendency for research to work outward from the entrepreneur to consider other factors and policies, what might be termed the supporting cast of policies which assist entrepreneurs achieve their various objectives. These related policies involve such activities as the provision of finance for entrepreneurship, and advice and financial assistance for the firm. They may also include to some extent policies that provide these forms of support in a bundle in either time or space (for example, incubators) or both. The attempt to designate areas of action as relevant has been extensively widened and, in some cases, the argument for support to entrepreneurship takes on the form of lobbying for action by government are very broad in scope (Kauffman Foundation, 2012). The next section of this report examines how policy makers justify their policies on entrepreneurship and shows where currently, the limits of action lie.

\subsubsection{Systematic Approaches}

Entrepreneurship policy while having its own specific rationales can also be considered within the context of broader policies to promote economic growth, development and sustainability. The European Union, for example, has sought to develop its framework for entrepreneurship policy across multi-country context and within a single programme, the Entrepreneurship and Innovation Programme (EIP), consisting of six streams of activity (see Figure 3). This requires systematic policy coordination at all levels and between all levels. The EIP is an umbrella project in effect - to promote entrepreneurship that covers financial assistance to firms, promoting the Enterprise Europe network, and supporting eco-innovation. The programme is important as a form of support to entrepreneurship because of the scale of funding, although of course the amount of money is to be spent across the whole of Europe. Example of activities (parts E and F for instance) directed at promoting entrepreneurship include: a) the Community programme for the reduction of administrative costs; b) IPR Helpdesks (European Helpdesk on IPR and China SMEs Helpdesk); c) E-skills (study; conferences; seminars; best practice exchange); d) European SME week/ European Charter for Small Enterprises: (conferences; workshops dissemination of good practice and information); e) Information campaign on CE marking; and f) SME performance review (studies; workshops; meetings).

A recent evaluation of the programme (Centre for Strategy and Evaluation Services, 2011) examined its relevance, efficiency and effectiveness. However, the real impacts of the programme in terms of the growth of enterprises, generation of employment and contribution to welfare were not able to be assessed as, at the time of evaluation, the programme was still two and a half years from completion. Nevertheless, the review, largely based on a survey and monitoring with high profile interviews about what the participants and beneficiaries believed were useful, came to a number of conclusions on operational performance and early and intermediate inputs, including the following:

- That the programme was particularly effective at the Europe wide level in addressing the needs, problems and issues (points A-F, diagram 2) set out;

- That the overall objectives were coherent and the implementation processes were integrated measures implemented by member states;

- That it was on track to achieve the anticipated impacts expected of it; and, 
- That stakeholders believed the budget and the dedicated resources were at the appropriate level.

Table 1. EIP Budget

\begin{tabular}{|l|l|l|}
\hline Objective for & $\begin{array}{l}\text { Budget allocated } \\
\mathbf{2 0 0 7 - 2 0 1 1}(\mathbf{m} \in \mathbf{s})\end{array}$ & $\begin{array}{l}\text { Percentage of } \\
\text { total }\end{array}$ \\
\hline A- Facilitate access to finance & 798.2 & $53.6 \%$ \\
\hline $\begin{array}{l}\text { B- Create an environment favourable to SME } \\
\text { cooperation }\end{array}$ & 325.6 & $21.9 \%$ \\
\hline C- Promote all forms of innovation in enterprises & 122.2 & $8.2 \%$ \\
\hline D- Support eco-innovation & 178.8 & $12.0 \%$ \\
\hline $\begin{array}{l}\text { E- Promote an entrepreneurship and innovation } \\
\text { culture }\end{array}$ & 35.4 & $2.4 \%$ \\
\hline $\begin{array}{l}\text { F- Promote enterprise and innovation-related } \\
\text { economic and administrative reform }\end{array}$ & 29.2 & $2.0 \%$ \\
\hline Total & 1489.4 & 100.0 \\
\hline
\end{tabular}

\subsection{Entrepreneurialism: Policy Rationales}

\subsubsection{Introduction}

Why then should government adopt a policy for entrepreneurship or entrepreneurialism? The economic rationale for public intervention in relation to entrepreneurship rests on distortions and market failures in the economy. These result, for the most part, from information asymmetries (Storey, 2005; Audretsch et al., 2007). We consider these policy justifications in turn below, outlining the conditions that give rise to the market failures and what solutions have been proposed. We believe on reviewing the literature that the first two of these arguments provide the rationale for entrepreneurship policy. Access to finance and R\&D and innovation related market failures provide the justification for other forms of policies not considered here.

\subsubsection{Lack of Awareness}

Firstly, there is a lack of or low awareness among (young) individuals of the potential benefits of starting a business (Storey, 2005). This can be met by for example education policy with an entrepreneurial element that can raise awareness and provide some training to the young to the benefit of an entrepreneurial career. In response to this first form of market failure, educational and cultural policies are justified. These have various targets and can include those already in work, the unemployed, and students. The aim of such policies is to promote a change in outlook and value system to the point that the individuals (and society at large) will become more entrepreneurial. Action within this framework could be specific in the sense of targeted at individuals; but it could also be achieved through general diffusion, what might be termed a broadcast model of transmission.

\subsubsection{Information Problems}

Second is the failure arising from ignorance on the part of business owners of the benefits of obtaining external advice from experts. Such information imperfections can be used to justify public subsidies directed to management training or facilitating specialist advice for small and growing firms. An important distinction to make here is between support to the firm and support to the entrepreneur. Specialist advice provision, which can be provided through 
business coaching or mentoring, addresses difficult and often strategic questions that face the entrepreneur. This situation specific advice is nearly always given actively, that is to say, the entrepreneur will not know before the advice is given, what kind of problem they or their company will face. More general advice can be given less actively, and may involve subsidized forms of information provision endorsed by government and therefore of assured quality of a very general kind that reduces the observation and search costs faced by the firm.

\subsubsection{Access to Finance}

A third type of information failure relates to access to finance. The market for credit is particularly vulnerable to information asymmetries. As you firms have little or no track record and or collateral they tend to be credit rationed in financial markets as financial institutions are unable to fully assess their risk. Intervention in the form of credit guarantee schemes rests on this kind of failure. A different study in the series (Access to Finance) has examined this form of support separately.

\subsubsection{The Positive Externalities of Investment in R\&D and Innovation}

Finally, intervention can be justified when it is necessary to align private and social interests. A public subsidy can be utilised to make it privately worthwhile for the firms to undertake projects that are in the interests of society which would not under normal circumstances provide sufficient returns. The classic example is policies to promote innovation. Without subsidies the formation and growth of technology based firms would be sub-optimal. Thus the potential for positive externalities can be used to justify policies to promote Science Parks or the public funding of seed capital programmes focused on technology-based small firms

\subsubsection{When there is doubt over market failure: the case of incubators}

As we have noted above, significant public support to innovation is given within the contexts of spatial or location based activities, and in the case of entrepreneurship support, this effort is sometimes directed at entrepreneurs within business incubators, sometimes referred to as incubators. However, the general case cannot be made that incubators can only work with government subsidy because the operation of a significant number of privately funded incubators suggests that there is an effective market for services of this kind. On closer examination of the operation of incubators as has been conducted very recently (Dee et al., 2011) it is clear that there is a continuum along which incubators can be placed in terms of the level of government support they receive, at one end of which there are many incubators that operate without public subsidy.

\section{Scope}

\subsection{Variety of Measures}

Consideration of the policy support to entrepreneurship leads quickly to the realization that this is an area where entrepreneurship policies in the strict sense of being directly focused on entrepreneurs are strongly connected to other policies considered by other reviews in this series of reviews for NESTA. These other policies have potential but under researched impacts upon entrepreneurship (e.g. the propensity to start a business, the costs of operating a business, the taxation implications for direct or indirect involvement in entrepreneurial activity), but consideration of these activities in conjunction with entrepreneurship schemes is clearly 
outside the scope of this piece of work. Moreover, policies that are focused on the entrepreneur in a narrow definition are sometimes provided together, making assessment of impact difficult.

\subsection{The Selection Criteria of Financial Contribution}

A further issue of subject matter clarification is that of the distinction between finance and nonfinance schemes. Some of the schemes that might be classified as entrepreneurship are "free at point of delivery" such as educational programmes in the schools. Such schemes are relatively simple to classify. Children do not have money to pay for these; but moving along the spectrum of measures, it is not so easy to designate a measure as either "financial" or "not financial". The example presented by coaching reveals how difficult the distinction between financial and nonfinancial is in practice. Coaching, which we believe is an important entrepreneurial measure can be subsidized or free. For this reason we have sought to relax the distinction between financial and non-financial as policy measures frequently fit into either category. Rather than consider these separately we feel it is better to consider the measures as single types.

We note also the importance of distinguishing between firm creation and measures focused on existing entrepreneurs. In order to focus our work, it was decided that we would investigate measures that target would be entrepreneurs and those in the earlier stages of an entrepreneurial career. According we did not look at measures that are more widely focused, i.e. on individuals that are already entrepreneurs.

We have covered a range of measures that seek to address a number of market failures. In particular we focused on policies that support culture change and entrepreneurial education and on policies to ameliorate information asymmetries. Some policies we have examined aim to address more than one goal in that they aim to correct more than one market failure. We call these multiple measures. Amongst the multiple measures considered we have noted a number of policies or programmes to provide financial assistance to firms ranging from venture capital to loan guarantees. These polices have been excluded from this report as they covered elsewhere.

\subsection{A Framework for the Presentation of Findings}

Our review of findings arranges the measures we have examined according to the market failures with which they deal. As access to finance is covered by a separate study, we have therefore three main categories under which we consider the measures. We draw conclusions then at the policy justification level in the first instance.

\section{Summary of findings}

\subsection{Classification of Schemes}

As we note above, our presentation of findings is undertaken by grouping the reviews of measures according to the market failure with which they deal. Mostly, this categorization of the measures and policies by reference to the failure to which they are addressed is satisfactory. We do however have one section where measures that are in combination with other initiatives are considered as this type of measure is relatively common. 


\subsection{Schemes to Promote Cultural and Behavioural Change}

Policy makers the world over have recognised the importance of entrepreneurship in the quest for economic development and support instruments like entrepreneurship education to increase levels of entrepreneurial activity. Entrepreneurship education is considered integral to creating a culture for entrepreneurship and there has been a significant increase in the use of entrepreneurship education in schools, colleges and universities in Europe and elsewhere. ${ }^{5}$

Studies of the impact of entrepreneurial education adopt various proxies for entrepreneurship including intentions to become an entrepreneur, the feasibility of entrepreneurial ventures, and competencies associated with entrepreneurship (Lepoutre et al., 2010). However the results of such studies are mixed. Some studies find entrepreneurship education impacts positively on perceived attractiveness and feasibility of starting new business activities while others find evidence that such effects are negative (Oosterbeek et al., 2010). Such inconsistent results, as noted by a number of authors (von Graevenitz et al., 2010; Lange et al., 2011; Lorz, 2011) stem from various methodological short-comings. Few studies adopt a pre-post design or include a control group. Few take account of the effect of the time lag. If the lag between starting a business and graduating is several years, then there may be other motivating factors that explain the decision to start a business. Finally many studies ignore the effect of self-selected participants predisposed to entrepreneurship which is likely to bias results in favour of educational interventions.

Oosterbeek et al. (2010) evaluate the impact of the student mini company scheme (SMC) on students' entrepreneurial competencies and intentions using an instrumental variable approach and a difference in difference framework ${ }^{6}$. They draw their data from a vocational college in the Netherlands that offered the scheme, part of the Junior Achievement Young Enterprise programme, at one of two of its locations providing similar Bachelor's programme. The latter provided a natural control group but since students may have self-selected into different school locations. Location choice (and thus treatment) is instrumented to account for changes in outcome variables due to unobserved differences between the students of both locations.

\footnotetext{
${ }^{5}$ While we focus on entrepreneurial education as the prime example of policies bringing about cultural change we admit that other types of policies can also result in cultural change. For example, Cooper (2003) writing about the US SBIR, which is a financial support programme covered elsewhere in our report series, Cooper has argued that the programme, as well as achieving impact by providing funds to entrepreneurs, has indirect effects upon firms, one of which is termed the "demonstration effect". This is where examples of successful SBIR project firms lead other potential entrepreneurs to start a business.

${ }^{6}$ The SMC, part of the internationally renowned Junior Achievement Young Enterprise programme, is the leading entrepreneurship education program in secondary schools and colleges across the US and Europe. The SMC program involves students' taking responsibility as a group, for a small sized and short time business, from its setting up (usually at the beginning of the school year) to its liquidation (usually at the end of the school year). Students get into contact with social and economic reality in the real business world out of the school. The activity takes place in class within the established curriculum, but may also be continued outside the school as a voluntary activity for the students. Each mini-company is supported by one or two advisers coming from the business world and sharing their experience with the students
} 
Entrepreneurial competencies were measured using the E-Scan Test (Entrepreneur Scan Test), a validated self-assessment test based on 114 items which are converted (loaded) into 10 traits and skills identified as important in the entrepreneurship literature. While traits may be invariant to the programme, skills such as market awareness for example, can be learned and improved through participation and changes are more likely to be observed. The test and a survey that included questions on background and likelihood of becoming an entrepreneur (intention) were administered at the start of the programme and again at the end both in the treatment location and the control. The results show that the SMC participation did not impact on entrepreneurial intention nor stimulate the skills of students. ${ }^{7}$ The effect on entrepreneurial intention was negative and significant. In other words, entrepreneurial intention in the control group was higher than for those in the SMC programme. In addition the effects on students' self-assessed entrepreneurial skills and traits were negative and not significantly different from zero. Oosterbeek et al. (2010) suggest that that the SMC programme may have had a discouraging or 'sorting' effect as in participating, students were able to form a more realistic assessment of both themselves as well as what it takes to be an entrepreneur.

Slavtchev et al. (2012) investigate the impact of entrepreneurship education on students' intentions to follow an entrepreneurial career path. They distinguish between short term intention (immediately after graduating) and long term (five years after graduating). Drawing on data collected from two student surveys in 2006 and 2008 respectively at the University of Otago in New Zealand, they identified students completing both surveys and used a differencein-difference approach to analyse changes in their entrepreneurial intentions in relation to attending entrepreneurship classes. In order to control for potential selection bias they limited the analysis to students who had no entrepreneurship aspirations either prior to enrolling on the course or who had not previously attended such courses. The difference in difference result showed that the intention to become an entrepreneur (or self-employed) immediately after graduation was $9.1 \%$ lower for students taking entrepreneurship courses relative to the control, although this result was not statistically significant. An alternative, but significant OLS estimate showed the intention of the treatment group to larger, $12.5 \%$ lower after controlling for academic departments.

Entrepreneurial education however seemed to impact on longer term intentions. Fifty percent (50\%) of students taking course developed entrepreneurial aspirations compare to only $21.1 \%$ of the reference group. The difference in difference estimate was significant and indicated that 28.9\% more students taking the course intended to become entrepreneurs or self-employed in the long term relative to those not taking such courses.

Von Graevenitz et al. (2010) develop a learning model in which entrepreneurship education provides signals to students. These signals enable students to evaluate their aptitude for entrepreneurial tasks. The model is tested using data from a compulsory course on Business Planning at the Munich School of Management for all students on the Bachelor of Science

7 A study of a similar scheme across secondary schools in Norway using a multilevel model finds participants had a positive attitude (they were creative, well educated and driven by opportunity) to entrepreneurs compared to non-participants (see lohansen et al., 2012). However this study was not concerned about intent and while having a control group did not employ a pre and post text design to fully understand if and whether the programme changed perceptions about entrepreneurship. 
curriculum. Students were surveyed at the start of the course and again at the end of the semester. The survey instruments were largely identical and covered issues such as attitudinal measures and assessments, confidence assessments, course impact assessments and ex ante and ex post entrepreneurial intentions. Answers to questions related to the feasibility of starting a business are used to measure signals students received about their entrepreneurial aptitude before and during the course.

The model enables von Graevenitz et al. (2010) to examine whether the variance and strength of student beliefs that they are entrepreneurs change by the end of the course; and the change in intention resulting from entrepreneurship education. Standard deviations of student's beliefs about their entrepreneurial abilities were computed for pre and post course samples of students who responded to at least one survey as well as three restricted subsets of those who participated in both surveys. The results show that the variance increases in all samples but von Graevenitz et al. (2010) are unable show that they are statistically significantly. However they find a significant increase in beliefs for the sample of students who do not update and who received strong signals before the course.

OLS estimations are used to analyse the relationship between the strength of students' intentions to become entrepreneurs (or avoid entrepreneurship) and several variables including pre-course beliefs, sex, religion and whether parents or friends are self-employed. The results show that the strength of students' intentions is positively related to the strength of pre-course beliefs, consistent beliefs (where signals received before and during the course are either both high or both low) and the interaction between the two, all of which are significant at either the $1 \%$ or $5 \%$ levels. While not employing a control group, von Graevenitz et al. (2010) argue that it was unlikely that students updated their beliefs on information outside the course since the contents of the course were very specific and not duplicated in other courses. However in line with Oosterbeek et al. (2010), these results suggest that entrepreneurial education strengthens (weakens) the intentions to become entrepreneurs and further that the consistency of signals received affects changes in students' intentions to become entrepreneurs.

\subsection{Schemes to Provide Information}

\subsubsection{Schemes to Provide Advice of a Standardized Form}

Schemes providing information and advice include general support to entrepreneurship across a whole range of challenges but there are some which are directed at specific types of business, usually SMES, and firms with particular aspirations. Our first example is of a programme in Canada in the Province of Quebec, the OPREX initiative, that aims to improve export performance of firms, particularly SMEs through A) Training and preparedness activities and services; B) Awareness activities and services; and C) Support/guidance activities and services: The review was conducted (Larivière, 2007) for the Quebec Ministry of Development, Innovation and Exports The evaluation notes the strong interest in the use of the scheme, a strong desire on the part of users of the scheme to continue to use it in the future. The evaluation noted that firms targeted were aware that they did not have the knowledge and understanding to undertake export activities successfully and therefore the targeting by the programme appears appropriate. "As regards export training and preparedness, $62 \%$ of trained clients said they were not equipped or were poorly equipped to assess the profitability of their export activities, $79 \%$ of them said they were not convinced to assign an employee to the "export" function, and more than half claimed that training would not have an impact on their 
ability to maintain or increase their exports level over the next two years. We also noted that a high percentage of respondents were unaware of certain existing resources that would be able to support them in their endeavours" (Larivière, 2007: v).

This issue is not however touched upon by the evaluation. The approach to evaluation is according to the Storey framework more of a monitoring exercise in that the assessments of impact are descriptive and do not employ any comparison cases, let alone matching or methods to remove selection bias.

The study by Wren and Storey (2002) examines the impact of the UK Enterprise Initiative, a publicly supported advisory assistance programme provided by private consultants, on the performance of SMEs as measured by sales turnover, employment and firm survival. . The study notes, as others have done, that the amount of government money spent on soft support to firms is large, yet the methods employed in the evaluation of these measures are limited in scope and rarely seek to measure additionality - the true net effect. Wren and Storey (2002) cited the rationale for the programme - market failures based on asymmetric information leading SMEs not to use existing forms of advice from the private sector which creates a justification for the government to operate a subsidized and higher quality service. Relative to a control group of firms, the analysis finds that the scheme encouraged firms to use outside consultants and this had positive impacts on firm performance. Using survival rate as a measure of performance the authors observe no effect in terms of the lifespan differences for smaller firms but medium sized firms appear to have a $4 \%$ improvement in their survival rates over the longer run. The selectivity corrected regression analyses indicated that assistance had an impact on sales and employment but this varied by firm size. For SMEs, the net impacts were increased sales (from $£ 127 \mathrm{~K}$ to $£ 151 \mathrm{~K}$ ) and employment (from 3.2 to 3.9 employees). In the case of medium size firms, annualized growth rates rose by about $10 \%$ (from $£ 846 \mathrm{~K}$ to $£ 921 \mathrm{~K}$ in sales and from 19.8 to 21.8 employees). For larger firms, the estimated impacts on employment were also about $10 \%$ (from 146 to 162 employees), but no significant impacts were found for sales.

The policy implication is that assistance to very small firms may be not as effective a way of promoting growth as supporting the larger SMEs which benefited significantly from the advice given under the Enterprise Initiative. In respect to the significant effects of the scheme in terms of sales turnover and employment, the authors suggest that a displacement effect may be occurring. Thus, positive impacts of the scheme in one area may well result in lower turnover in other areas.

Roper and Hart (2005) evaluate the performance effects of assistance to small firms in England provided by the Business Link (BL) programme over the 1996 to 1998 period. The programme was designed as 'one stop shop' approach to supporting SMEs. The overall objective was to coordinate existing SME support services by creating a fully integrated, local strategy for promoting business and enterprise. BL therefore sought to increase the use of business support by small firms, rationalise support provision by removing duplication and improve the quality of support services. Using a sample of assisted and unassisted business to control for selection bias, they found little evidence that BL assistance was being targeted effectively at firms with a track record of rapid prior growth and further that BL assistance over the 1996-98 period no significant effect on firms' sales, employment or productivity growth over the 1996-2000 period. By contrast excluding the control for selection bias results in a positive employment growth from BL assistance over the 1996-2000 period. 
In a subsequent study of BL, Mole et al. (2008) investigate the kinds of firms using the advisory services programme for SMEs; the types of firms benefitting most from such support; and the impact of programme participation on sales and employment growth. They use a nonexperimental approach with a regression model to control for group differences and difference in difference methods to eliminate potential biases from unobserved variables. A probit analysis showed that that BL participation was greater among younger, limited liability firms and among firms receiving BL contact and informational mailings. OLS results indicated that intensive use of BL assistance had a positive and significant impact on employment growth but not on the growth of sales. A difference in difference analysis showed that relative to control firms, BL firms experienced an overall average employment growth of $4.4 \%$ (5.4\% for firms with less than 20 workers and $7.6 \%$ for firms with over 50 employees). Effects varied across firms according to strategic orientation-for firms expanding into new markets employmentgrowth benefits were higher (11.7\%) compared to firms serving current markets (4.1\%), while it was $6.7 \%$ for firms using formal business planning processes compared $3.9 \%$ to those that did not. ${ }^{8}$

Rotger et al. (2012) uses a matching method to analyse the performance of the Denmark's North Jutland Entrepreneurial Network which provides advice and guidance to individuals engaged in the creation of new ventures. The Network offers 3 levels (L) of counselling products: basic counselling (assessing viability of the idea) provided by the local business centre (L1); counselling with private-sector advisors (eg formulating business plan) (L2) and extended counselling during the start up with private-sector start-up consultants (L3). By disaggregating a sample of participants that received at least L1 advice between 2002 and 2005 into three groups: those using only L1, those using L2 after completing L1 and those using L3 after completing both L1 and L2, and applying propensity score matching, Rotger et al. (2012) estimate the marginal effects of different levels by using a group at one level as the control for a group at the next level (e.g. L1 is the control for L2 and L2 for L3). They consider three aspects of performance: survival; employment and output, and conduct separate analyses for 20022003 and 2004-2005 because of a change in the programme in 20049. The analysis found that L2 participation increases two year survival rates by about $8 \%$ and four year survival rates by $5.2 \%$ while for L3 participants, two year survival rates increased by a further $7.6 \%$ and the four year survival rate increased by $6.4 \%$.

In terms of employees the average effects of L2 participation was 0.5 (for the 2002-2003 cohort), equivalent to one job created for every two firms assisted. However this seemed to be a short term effect as the coefficient was not significant in later years. By contrast, the employment impact for L3 firms while not significant initially, became significant in the second and third years cautiously indicating a strengthening of the impact over the longer term. In respect to turnover, although L2 and L3 impacts are positive and significant, they seem to be

\footnotetext{
8 The relevance of business planning support for start ups cannot be overemphasized. Chrisman et al. (2005) for example, using data from the Small Business Development Center (SBDC) programme in Pennsylvania in 1992, 1994, and 1996 showed a strong and significant relationship between what he terms guided preparation provided by the Center and sales and employment in firms 3 to 8 years after start up.

9 Separate analyses were done for 2002-2003 and 2004-2005 due to a change in the programme in 2004. The result for 2004-2005 are patchy thus we focus more closely on the 2002-2003 cohort.
} 
moving in opposite directions with the L2 impact appearing to be falling over time from 178,000 DKK one year after participation to 127,000 DKK 3 years after participation while the L3 average effect increased from 225,000 DKK after the first year to 357,000 DKK three years after participation.

Norrman and Bager-Sjögren (2011) have carried out a detailed study of a specific measure, the Swedish Innovation Centre using a matched pair analysis. This methodology provides some detailed insight into the net effects on firms of entrepreneurship support. This programme assisted 'innovators in their absolute earliest phases of development with financial capital, advice and networks'. The duration of the programme was the period 1994 and 2003. The authors believe that the SIC was a typical programme in that its main purpose was 'to create a better innovation climate in Sweden ... where people's attitudes to innovators is positive. And where it is easy for an innovator to receive help to develop his or her concept to a commercialized product or service' (SIC, 2002: 24)" (Norrman and Bager-Sjogren, 2011: 604). The programme was therefore supporting entrepreneurial skill development and at the same time, attempting to realize new technologies with support that included financial assistance. The programme was not confined solely to skills development therefore. The authors note also that the programme did not have clear goals and an explanation of how it would work exactly: "Although SIC is a public programme, the official publications of SIC have not revealed any clearly described 'programme theory' that includes defined targets against which to measure. Turnover (sales) and number of employees were both mentioned as desirable outcomes (SIC, 2004), albeit no explicit evaluation indicators were formulated. This lack of targets blocks estimates of the impact in the case of goal attainment" (Norrman and Bager-Sjogren, 2011: 606). The analysis carried out in the paper focuses upon the impact of the programme as a whole and does not distinguish between financial support to the firm and support in the form of entrepreneurship education.

Approaching the issue of entrepreneurship from a labour market policy ${ }^{10}$ perspective, $\underline{\text { Caliendo }}$ and Kunn (2011) evaluate the effectiveness of two start-up programmes in Germany: the startup subsidy' (Existenzgründungszuschuss) programme, introduced for the unemployed in 2003 and the 'bridging allowance' (Überbrückungsgeld) programme, implemented in the late $1980 \mathrm{~s}^{11}$. Rather than compare the relative success of the two programmes with respect to the success of the businesses outcomes (output growth, employee growth, etc.) they match the labour market outcomes of the formerly unemployed 'entrepreneurs', those participating in the aforementioned programmes with other unemployed individuals. Outcome variables are 'not

${ }^{10}$ In recent years policy-makers have sought to actively promote entrepreneurship and enterprise as an alternative to waged employment, and, particularly, unemployment. Correspondingly entrepreneurship research has begun to distinguish between opportunity entrepreneurs, who voluntarily engage in entrepreneurship to pursue a business opportunity they spotted, and necessity entrepreneurs, who are pushed into entrepreneurship (self-employment) because of negative external forces, such as layoff and a subsequent lack of available paid-employment work (Dawson et al., 2009; Fossen and Buttner, 2012).

11 These programmes accounted for $8 \%$ and $12 \%$ respectively of the $€ 12$ billion the German government spend on unemployment measures such as vocational training programmes, job creation schemes, employment subsidies and self-employment of formerly unemployed individuals in 2004 . 
unemployed'12 and 'in paid or self-employment' and personal income. Using propensity score matching and difference in difference analysis, they analyse the employment outcomes of participants for up to 56 months after programmes started.

The analysis showed positive and significant effects over time for the outcome variables. By the end of the period of analysis (56 months) participants in the start-up subsidy (bridging allowance) have a $15.6 \%(10.6 \%)$ higher probability of not being registered as unemployed compared to non-participants. In terms of integration into the labour market, that is being either self-employed or regular employed, the employment probability of participants is $22.1 \%$ higher for start-up subsidy group relative to the control group and $14.5 \%$ in the case of the bridging allowance participants. Positive and significant differences are also registered for different measures of income. Start-up subsidy (bridging allowance) participants have a monthly working income which is €435 (€618) higher than non-participants while for total income (income from self or paid employment plus transfer payments) the differential is $€ 270$ (€485).

A separate analysis of the bridging allowance scheme mentioned above (Oberschachtsiek and Scioch, 2011) focused more specifically on support activities (training and coaching) ${ }^{13}$ that are provided in addition to the financial subsidy to help promote entrepreneurship activities among the unemployed. Using a propensity score matching procedure, Oberschachtsiek and Scioch (2011) compare outcomes between a comparison group, individuals who did not receive the extra support but who nevertheless received a bridging allowance to the treatment group. The key outcome variable for their analysis is the duration of self-employment. Thus they compute two measures: the likelihood of quitting self-employment during the first 36 months and the probability of survival between different time periods. In other words, they investigate whether supports schemes enable the development of entrepreneurial activities. If the schemes work, they there should be fewer exits from self-employment either into unemployment or paid employment.

Overall the analysis shows that the treatment effects (difference between the treated and control groups) are relatively low and in most cases statistically insignificant. This suggests that (on average) additional support does not contribute to an increase in the duration of selfemployment. In the case of training, statistically significant effects are found for 'exits into unemployment' so that additional support is associated with an increase in exiting selfemployment into unemployment. By contrast, coaching significantly reduces exits into dependent employment; business founders who receive coaching support are less likely to enter dependent employment when quitting self-employment.

Fairlie et al. (2012) used data from Project GATE (Growing America through Entrepreneurship) to analyse the impacts of entrepreneurship training. This was a demonstration project organised by the U.S. Department of Labor and the Small Business Administration (SBA) in

\footnotetext{
12 Since the primary research question relates to if programme participation lowers the risk of returning to unemployment they construct a variable that treats registered unemployment as a failure and all other possible states as a success.

13 Training courses aimed to enhance preparatory skills (courses lasted between 4 and 12 weeks) while coaching provided qualified assistance during the first year of the start-up.
} 
which 4,198 applicants were randomly assigned to either the programme group or a control group. ${ }^{14}$ Those in the programme group were eligible to receive free best practice training services while no services under the programme were offered to those in the control group. Data in relation to outcome measures were collected in follow-up surveys at 6 and 18, and 60 months after treatment assignment.

Fairlie et al. (2012) estimate the average treatment effects across the entire sample and suggest that GATE had limited impacts on ultimate outcomes. In terms of business ownership, the initial positive effects of business training dissipated over the long run. While the treatment group had a 5.2\% higher rate of ownership at the 6 month survey, in the follow-up survey, this declined to $2.2 \%$ (statistically insignificant) and after the 60 month period, the levels of ownership between the groups were identical. The results are similar for other measures of business performance. Taking into account the cost of the programme and the absence of any tangible effects, Fairlie et al. (2012) conclude that entrepreneurship training was not a cost effective way of increasing levels of entrepreneurship.

\subsubsection{Schemes to Provide More Specific and Situational Advice}

\subsubsection{Coaching}

In recent years, governments have begun to support advice to SMEs through subsidy of business coaching. Coaching can be a diverse form of advice giving, including specific information on such issues as marketing (covered by Wren and Storey, 2002) but also more generalized advice to new business owners whose background and experience in their new roles may be limited. While policy initiatives that support advice giving have been justified on the basis of market failures, other justifications that emphasize the subjectivity of the SME and entrepreneur have also been proposed.

These subjective, entrepreneur based assessments of need are based on Austrian (neoAustrian) conceptions of economic action. They lead to different views of how SMEs and entrepreneurs should be supported. The neoclassical view that views markets as systems that can be affected by information asymmetries leads to attempts to promote standardized approaches, what Lambrecht and Pirnay (2005: 93) term "objective" and are "delivered in an expert and solution oriented way". By contrast, the neo-Austrian approach focuses on the need to develop help that is specific, and answers the often unique needs of the entrepreneur.

The methods used in the analysis by Lambrecht and Pirnay (2005) did not employ a true counter-factual analysis and only compared firms that had been helped with typical firms (the comparison using match firms and the taking into account of selection bias was not carried out). Nevertheless, the conclusions suggest support amongst the user firms for the measures. The self-reported additionality is $63 \%$ in this study, i.e. $63 \%$ said that that without the support they would not have used a private consultant. Regarding future use, $26 \%$ of the users firms said that they would use an external consultant again, even if the help was to be given without a subsidy. The study reports three main reasons for the hiring of a consultant: the reasons are: quality enhancement of goods and or services' b) diagnosis of the enterprise' and c) organisational improvement. Modelling of changes over time was done using a comparison with a set of firms

${ }^{14}$ Around half were offered free entrepreneurship training services at 14 different SBDCs and non-profit community-based organizations (CBOs) located across 7 cities in 3 states 
who did not use the services. This analysis revealed however that there were no "significant impacts on net job creation turnover or financial indicators" form the use of private external consultancies. While this study is focused on a scheme that provided direct and "operational services in a solution oriented way" (Lambrecht and Pirnay, 2005: 105), the assistance given is likely to have been broad enough to constitute entrepreneurship support. The authors' main conclusion is however that support to entrepreneurs needs to be more customized and focused upon "the entrepreneur and his objectives" (Lambrecht and Pirnay, 2005: 107).

Within the support measures provided by the ERDF funded North West ERDF Operational Programme (2007-2013), a coaching scheme was introduced to promote entrepreneurship. The North West Regional Development Authority area introduced a coaching scheme in parallel with the other RDAs across England and Wales. All RDAs were required to implement such schemes (East Midlands Development Agency, 2005). A box below identifies the UK government's approach and understanding of coaching and its role in the promotion of entrepreneurship. 
Table 2. Coaching: UK Approach (East Midlands Development Agency, 2005)

Coaching is not 'therapy' by another name although the key theoretical underpinnings, models and techniques found their origins in the field of psychology and associated therapies like gestalt \& cognitive behavioural therapy which have broad ranging applications in both organisational and personal contexts. The key difference between coaching and the therapies is that coaching does not seek to resolve the deeper underlying issues that are the cause of serious problems like poor motivation, low self-esteem and poor job performance. Coaching programmes are generally more concerned with the practical issues of setting goals and achieving results within specific time-scales. Therefore, the basic premise of high growth business coaching is that it is a process that enables both individual and corporate clients to achieve their full growth potential. Coaching and mentoring share many similarities so it makes sense to outline the common things coaches and mentors do whether the services are offered in a paid (professional) or unpaid (philanthropic) role.

$>$ Facilitate the exploration of needs, motivations, desires, skills and thought processes to assist the individual in making real, lasting change.

$>$ Use questioning techniques to facilitate client's own thought processes in order to identify solutions and actions rather than takes a wholly directive approach

$>$ Support the client in setting appropriate goals and methods of assessing progress in relation to these goals

$>$ Observe, listen and ask questions to understand the client's situation

$>$ Creatively apply tools and techniques which may include one-to-one training, mentoring, facilitating, counselling \& networking.

$>$ Encourage a commitment to action and the development of lasting personal growth \& change.>Maintain unconditional positive regard for the client, which means that the coach is at all times supportive and non-judgmental of the client, their views, lifestyle and aspirations.

$>$ Ensure that clients develop personal competencies and do not develop unhealthy dependencies on the coaching relationship.

$>$ Evaluate the outcomes of the process, using objective measures wherever possible to ensure the relationship is successful and the client is achieving their personal goals.

$>$ Encourage clients to continually improve competencies and to develop new developmental alliances where necessary to achieve their goals.

$>$ Work within their area of personal competence.

$>$ Possess qualifications and experience in the areas that skills-transfer coaching is offered.

$>$ Manage the relationship to ensure the client receives the appropriate level of service and that programmes are neither too short, nor too long. a. How does the coaching differ from other forms of support? There are differences between coaching and other approaches to supporting rapid improvements in business performance. The table below contrasts three different approaches to coaching \& mentoring, counselling and consultancy. 
Table 3. Coaching and Mentoring and Consultancy (East Midlands Development Agency, 2005)

\begin{tabular}{|c|c|c|}
\hline Coaching & Counselling & Consultancy \\
\hline $\begin{array}{l}\text { - } \quad \text { Actively untaps potential. } \\
\text { - } \quad \text { sine tunes and develops } \\
\text { Development activities are } \\
\text { designed to suit client's } \\
\text { personal needs and } \\
\text { learning styles. } \\
\text { - } \quad \text { pliminates specific } \\
\text { - } \quad \text { Can focus on interpersonal } \\
\text { skills, which cannot be } \\
\text { readily or effectively } \\
\text { transferred in a traditional } \\
\text { training environment. } \\
\text { Provides client with } \\
\text { contacts and networks to } \\
\text { assist with furthering their } \\
\text { career or life aspirations. } \\
\text { Performed in the 'live' } \\
\text { environment } \\
\text { Highly effective when used } \\
\text { as a means of supporting } \\
\text { training initiatives to } \\
\text { ensure that key skills are } \\
\text { transferred to the 'live' } \\
\text { environment. } \\
\text { Coaches and mentors } \\
\text { transfer the skills to the } \\
\text { client rather than doing the } \\
\text { job for them. }\end{array}$ & 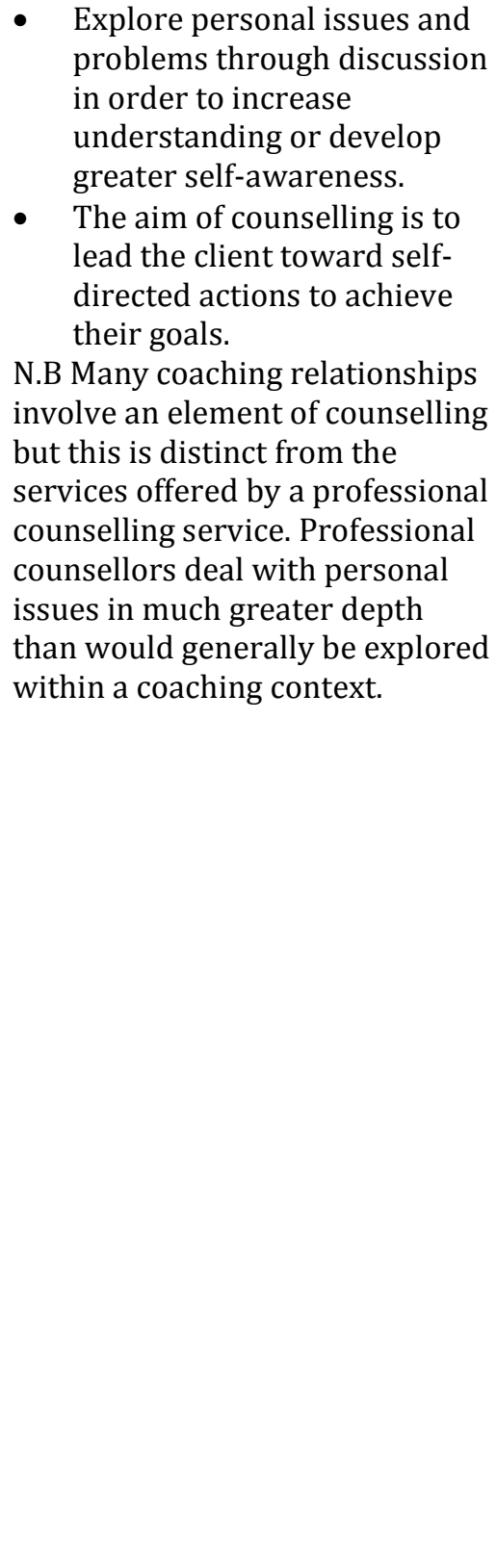 & $\begin{array}{l}\text { Focus is on developing } \\
\text { organisational practices, } \\
\text { processes and structure. } \\
\text { Role generally more strategic } \\
\text { and often used to instigate } \\
\text { and design broad ranging } \\
\text { change programmes } \\
\text { Consultancy frequently } \\
\text { involves expert advice about } \\
\text { specific issues and } \\
\text { organisational processes. } \\
\text { Consultants are often } \\
\text { brought in to provide } \\
\text { specific 'solutions' to } \\
\text { business problems and } \\
\text { needs Consultant does the } \\
\text { job for the organisation, } \\
\text { rather than the } \\
\text { employee/client becoming } \\
\text { upskilled to do the job } \\
\text { themselves. } \\
\text { N.B. The term consultant coach is } \\
\text { often used when the coach is } \\
\text { external to the organisation and } \\
\text { therefore offering services on an } \\
\text { 'external' or 'consultancy' basis. } \\
\text { Thistinguishing between them. } \\
\text { consultancy per se. } \\
\text { Coaching and mentoring has } \\
\text { been offered by consultancy } \\
\text { companies for many years, even } \\
\text { though it is not } \\
\text { specifically 'consultancy'. It is } \\
\text { only recently that people have } \\
\text { begun drawing a distinction } \\
\text { which in some cases, like the } \\
\text { dinction between coaching and } \\
\text { menting is not useful in } \\
\text { distiome as }\end{array}$ \\
\hline
\end{tabular}

Evaluations of coaching schemes are difficult in that engagement with firms varies significantly. Needs are different across firms and the action provided by coaches varies also. Such schemes are also support to entrepreneurs but do not encourage entrepreneurship as those receiving assistance are already running their own businesses.

The NESTA study on mentoring, which covers a number of coaching programmes and not only those directed at the creative industries, reaches the following conclusions which concern operational issues and do not set expectations about the impact of such schemes (NESTA, 2009a): coaching helps entrepreneurs tackle a range of problems within a firm, but particularly people related issues; there may be greater suitability for coaching with the creative industries; relationships - i.e. the coaching period should be within a period of between six months and two years and meeting should be on around a monthly basis' personal matching between mentors 
and mentees is vital for the success of the mentoring; invariably mismatches arise between personalities, so arrangements must be made to allow coaches / mentors and those they assist to break off their relationship if tension and disagreement occurs; expectations on both sides need to be carefully managed 15 .

Other reviews of coaching as an activity have highlighted the following issues: the variety of approaches (as noted by the EMDA review) (Brockbank, 2008); the specific characteristics of the coach and how they impact upon the coach's effectiveness (Feldman and Lankau, 2005) and also for more technical discussions of this see Wycherley and Cox (2008); the difficulties of establishing a coaching profession to maintain standards and to ensure a coherent vision (Hawkins, 2008); the role of leaders in the coaching process (Peterson and Hicks, 1995); and coaching as means of promoting organisational change (Stober, 2008).

The early review of expert help (The Expert Help Scheme) including coaching for entrepreneurs in Scotland by Turok and Raco (2000) identified the scheme as one that was the first in the area of its type. There was insufficient targeting and precision it was felt and that the offering of help was often too generic in many instances. Evaluation of the characteristics of firms showed that these varied significantly and that a simple offering of support would not meet the needs of firms. A proposal was made in the evaluation that a more strategic relationship be developed between the support agency and those firms most requiring help. The review did not use any of the more rigorous methods with which to obtain a measure of additionality.

A review of the evaluation of coaching performance by their clients by Gale et al. (2002) ${ }^{16}$ and cited in Feldman and Lankau (2005) suggests that in regard to the operation of private coaching schemes, it is difficult to make assessments of the impact and quality of the service offered: "Evaluations that coaches receive from their clients are mainly subjective in nature and are not empirically valid measures of coaches' actual effectiveness. In this particular survey, $16 \%$ of coaches actually reported that they never followed up with their clients." It is therefore not perhaps surprising if the same difficulties that affect private provision of coaching are also likely to affect public provision. Feldman and Lankau (2005) note that the academic research on the outcomes and impacts of coaching are very limited; far more common are practitioner publications on coaching but these lack any empirical and robust methods of impact assessment.

\subsection{Multi-Instrument Schemes}

\subsubsection{Schemes Combining Activities in Time}

We note that support programmes may combine initiatives that derive their justification from different market failures. In it in fact especially common within the entrepreneurship policy for programmes of action that deal with market failures of information to be combined with programmes that provide access to finance. Here we consider schemes that operate at different scales and which involve a combination of activities to support firms or entrepreneurs. Such schemes are difficult to classify and compare as they use different combination of measures.

15 It is surprising that no evaluations of the UK's high growth coaching programme pilots or full schemes have been made public.

16 Not a public scheme. 
One example of this use of a combination of policies is studied by Marxt and Piekkola (2007) who outline how different aspects of the programme offering interact with each other to achieve an effect by encouraging entrepreneurship.

The foundation of new companies has attracted world-wide attention for the past decades, as the emergence of small firms has been increasingly regarded as the spine of a healthy economy. In order to support entrepreneurship, most Western countries have included several supporting features into their national (and regional) systems of innovations (NSI). An example of such can be observed in the initiative of "venture - companies for tomorrow", a Swiss-wide business plan contest. This research is aiming to investigate whether such a support initiative does have a positive perceived impact on the creation of new companies. As a first step a qualitative study ( $\mathrm{n}=115)$ was conducted to analyze the impact of the initiative on participating companies in 2006. Initial results show that the importance of networking, feedback and coaching was perceived to be the most useful features of the initiative. Also, the presence of a sparring partner was seen to be helpful in writing a business plan. Additionally, it can be concluded that one third of the respondents had founded their own company after the competition, which indicates a positive overall impact of the competition in its aim of fostering entrepreneurship

The Dutch SME and Entrepreneurship Policy Program which operated between 1982 and 2003 is a combined initiative promoting entrepreneurship awareness and skills with financial assistance, in this case with loan capital. Just as in the previous example of the European Union's Entrepreneurship and Innovation Programme, advice is combined with financial assistance in a package (Kuiper, 2011). The programme delivers entrepreneurship education and skills. These took the following forms: "Entrepreneurship courses and information provision and advice constituted the communicative instruments in the SME policy program and were aimed to guide (prospective) entrepreneurs into the rules of the game of business set up via the institutional framework of the Establishment Act, SME Instrumentarium, and general (economic) policies including the tax code, labour and social security issues et cetera" (Kuiper, 2011: 13). The evaluation compares the role of reviews of policy with changes that were taking independently in the country that promoted entrepreneurship. No systematic comparisons are made and no quantitative methods are used.

The review of the North East Entrepreneurs Forum undertaken by EKOSGEN, a consultancy, examines the performance of a scheme intended to promote entrepreneurship. We regard this as a combination scheme in which support to entrepreneurs and entrepreneurship is provided through a third party and includes a range of activities of which coaching is an important part where networking, meetings, social events are provided. The scheme derives from the UK's Regional Economic Strategy (RES), adopted in 2008, to promote entrepreneurship in the regions. This policy operated in the North East of England, through a variety of mechanisms, one of the most important being the Entrepreneurs Forum, a pre-existing and private body that had, prior to the launch of the RES, sought to promote entrepreneurship through a variety of mechanisms of its own.

The One North East Programme aimed "to increase the number of business start-ups, their survival and their growth through innovative forms of support and awareness raising activities: stimulating future entrepreneurs; facilitating start up; and mainstream start up and business support" (EKOSGEN, 2010: 8). The main aim of the RES was to increase GVA per head from 80\% to $90 \%$ of the national average by 2016 . The Entrepreneurs Forum activity to promote 
entrepreneurship was accompanied by a further initiative, the project "If we can, you can". This project has been subject to a separate evaluation.

The evaluation of the Forum reports high levels of additionality from the activities undertaken with the financial support from One North East. The activities of the Forum comprised the following: large events and conferences, where there might be inspirational and high profile speakers, including SME and student conferences, dinners, smaller meetings, and mentoring activities.

The evaluation uses both monitoring through self-reported views of the usefulness and impact of the programme's activities, and an assessment of impact that it is claimed gives an assessment of net programme impact or additionality. Assessment of the changes to the views and decisions taken by participants that relate to entrepreneurship, for example, did they become more interested or motivated to starting their own business, is undertaken by participant survey. A number of assessments are taken of how participation in the programme has affected participants' mindsets.

The methodology used to assess the net impact of the programme is that of the RDA Impact Framework. This does assess deadweight (a form of counterfactual) but does not address the selection bias issue. Assessment is made of gross impact of the programme in terms of jobs created and jobs safeguarded and turnover by extrapolating from the responses of the respondent firms to the whole of the set of firms that were known to have participated in the programme. However, the assessment of overall effects was altered to exclude a number of outliers. Furthermore, when it was found that the very high overall values of jobs created and jobs safeguarded was inconsistent with the reported turnover of firms, only the jobs created totals were used in the calculation of employment effects of the programme activities. The evaluation notes that there may be a tendency for over reporting of benefits: "there may be a degree of 'vested interest' in members reporting high returns attributable to the Forum" (EKOSGEN, 2010: 51). Overall, the evaluation reports a total net return of 30 million pounds on a government investment of 2.5 million pounds, assuming and deadweight of $47 \%$, leakage of $5 \%$, displacement of $21 \%$, substitution of $5 \%$ and persistence of the effects for 2.7 years.

A review by IPREG and consortium of researchers funded by the European Union has examined entrepreneurial policy in Sweden, Flanders, Austria and Poland (IPREG, 2011). A general conclusion is that entrepreneurship policies are more costly to operate than expected. Moreover, the evaluators claim that policy lacks clear goals and has few if any satisfactory measures of effectiveness. Entrepreneurship policy is closely linked in all countries to financial support, particularly for small firms (SMEs). The evaluation approach is one of auditing the support, and provides detailed information on the costs of the various forms of help given to entrepreneurs and firms. The review does not focus on efficiency and therefore does not use matched pairs on comparisons - matched pairs. No attempt is made to assess effectiveness and net impact - additionality - at the level of individual measures. However, the study does examine the coherence of measures and concludes that the market is diverse and a more segmented approach should be adopted: "The entrepreneurship policies also have a wide perspective and are directed to a wide audience including anything from primary school pupils through SME and growth companies to high technology entrepreneurs. In addition to target groups, the government should try to divide the market into distinct user groups (e.g. high-tech firms, eco-firms, etc.) by recognising their different needs, expectations and forms of behaviour. Even though the ultimate beneficiary of services involves the general public, some agencies 
need to work directly as specialists for small firms to meet the objectives of these firms" (IPREG, 2011: 82). In the case of Flanders, it was suggested that the use of more specialized agencies should be used than the existing bodies that deliver programmes.

The recommendations for Flanders cover a number of issues, some related to the overall design of support, other recommendations being very specific as to the operation and quality of particular forms of support, for example counselling and business advice, where, for example, the quality of private operators has been called into question: a) "Integration between the policy areas is not very clear and the fact that various policy areas related to entrepreneurship are the responsibility of different ministries, in some areas, leads to overlapping initiatives"; and b) "A related subject is that it remains a challenge to improve the quality of private sector counselling to supplement the public sector supply of business support" (IPREG, 2011: 83). The report also found that there were no methods in use to help obtain assessment of additionality.

The evaluation by IPREG of Austrian support has found significant support for entrepreneurship but a plethora of overlapping initiatives rather than a coherent approach with the implication that the level of support could potentially affect the incentives to start new firms.

Thus, on the issue of coherence, the report concluded:

"While all institutions contacted showed a strong commitment to Entrepreneurship policy and were most cooperative especially during the phase of data collection, in the course of this project it became clear that there is a jungle out there in Austrian Entrepreneurship policy." (IPREG, 2011: 128).

The report also observed that policy was being made at different levels, as well as in different areas:

"We could not identify a joint agenda in Entrepreneurship policy to which all funding institutions commit themselves and coordinate their activities. We rather found a multitude of isolated initiatives pursued by a large number of institutions on different administrative levels that strongly overlap." (IPREG, 2011: 128).

And the implications for incentives to start new business in Austria are clear, according to the report:

"At the same time location matters when setting up a company in Austria, because between states Entrepreneurship policy measures differ in focus and intensity as well as regarding the instruments employed." (IPREG, 2011: 128).

It was also noted that in the case of Austria, support for entrepreneurship focused more upon existing entrepreneurs rather than upon those wishing to start firms and who would not be classified as entrepreneurs. The evaluation of Austrian support is able to make a more detailed assessment of the costs of policy support and a number of measures are calculated that facilitate comparison across countries in terms of the amounts of money spent on policy initiatives.

A further measure is calculated that assesses the range of policy initiatives offered in each of the countries covered in the review. A measure, termed the comprehensiveness index is calculated to give an impression, based on expert judgement of people appointed by the review team, of 
the spread and depth of support given in this area of policy. No attempt is made in this study to assess the impact of policy.

\subsubsection{Schemes Combining Measures at a Location - Incubators}

In this section we consider the evaluations reported in the literature of those schemes that support entrepreneurship and skills development which are delivered within a specific location. However as Dee et al. (2011) note, the term 'incubator' can cover a wide spectrum of organisational forms including science parks, technology centres, business and innovation centres, virtual incubators, business accelerators, venture accelerators and a variety of other models. They characterise forms along a Management Support/Technology space as in Figure .

Figure 1. Management Support Technology Space Diagram

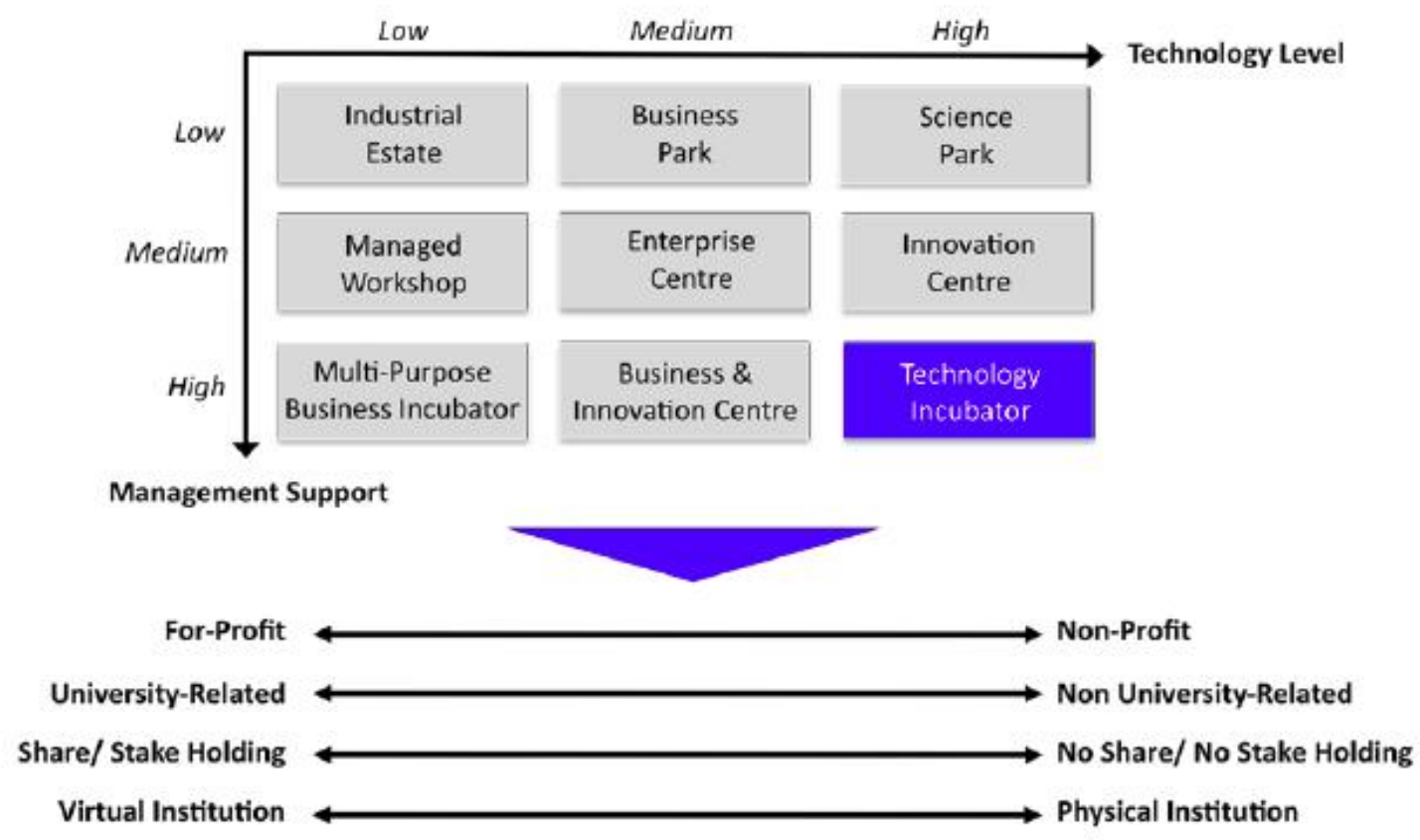

Source: Dee et al. (2012).

We noted earlier that these kinds of measures could be distinguished by their main target, those supporting entrepreneurs would be directed within incubators and those supporting firms would be delivered at firms (within science parks, clusters, or regions). Below we comment on the most recent literature that follows the extensive NESTA sponsored study carried out in 2011 (Dee et al., 2011) and the more recent paper by the same authors (Dee et al., 2012).

In general, the definitional ambiguity that abounds with respect to incubators and other SME supporting structures, the diversity of incubator models and appropriate performance measures have led to different research trajectories. Studies on incubator impacts are consequently fragmented with limited generalizability of findings. However considering the resources invested in incubators by governments, universities, research institutions, and other stakeholders, the central research question revolves around the societal return/impacts on such investments. Given the absence of a theoretical base for incubator performance evaluation (Ecorys, 2012), perspectives on the impacts of business incubators differ. 
Some authors are very critical about the effectiveness of business incubators. Tamasy (2007) for example reports that incubators can be a costly policy instrument. In surveying the literature Tamasy found that they provide only minor stimulus for individual start-ups; they do not increase the likelihood of firm survival, innovativeness or growth; and in practice only make a modest contributor to regional economic development. Such findings argues Tamasy do not legitimise the use of public funds to support the incubation industry.

Given the range of incubator types Tavoletti (2012) argues that performance evaluation should take account of the different goals of incubators which in turn reflect different stakeholder interests (Ecorys, 2012). Thus the analysis of outcomes and performance necessarily requires different evaluations of effectiveness. Measuring outcomes without reference to goals and stakeholder interests is meaningless (Bergek and Norrman, 2008; Ecorys, 2012).

In this vein a recent study Barbero et al. (2012) argues that performance depends on the type of incubator and its goals. The authors distinguish four incubator types: basic research, university, private incubators and economic development incubators, the latter of which they argue is geared toward the promotion of entrepreneurship. On evaluating the performance of a sample of 70 incubators in Andalucia (Spain) Barbero et al. (2012) conclude that there are significant differences in the performance of the different categories. Some types perform better in specific performance measures (firm growth, employment cost, etc.) while others perform worse. While economic development incubators performed poorly, university incubators performed satisfactorily, but the performance of private incubator and basic research incubators was gauged to be outstanding.

The limited empirical research that has been done using control groups to infer causality and counteract the selection bias in incubatee populations has been recently reviewed by Dee et al. (2011; 2012). They argued that many of the studies focused rather widely on science parks with physically distributed tenants thus what is observed might in fact be the impact of wider regional factors on new venture performance. They also find that performance measures used (e.g. revenue growth, employment growth, survival rate etc.) have their limitations with regard to assessing success of young ventures.

However a recent study by Schwartz (2012) anticipates some of these concerns by focusing more directly on incubators and adopting a longer term perspective (study covered a ten year period). Using a control group analysis Schwartz examines whether start-up firms in publicly supported incubators have higher survival rates than comparable non-incubator firms. Basing his analysis on 371 incubator firms (after their graduation) from five German incubators and a control group of 371 non-incubated firms, he finds that survival probability of graduated incubator firms is not significantly higher to non-incubated firms in any of the incubator locations. Moreover in three incubator locations, the analysis shows that incubator supported firms had a statistically significant lower chance of survival. A similar finding has been shown in the case of American incubators. Amezcua (2010) finds that while incubated firms outperform their peers in terms of employment and sales growth, they fail sooner. Such results raise questions about the impacts of incubation on firms' ability to sustain a growth path. 


\section{Lessons}

\section{General Observations}

The policies and programmes we have reviewed have sought to deal with the following market failures: a) awareness of the benefits of entrepreneurial careers; b) information asymmetries that prevent the market for expertise and information that serves early stage entrepreneurs from working properly. The market failures in the market for venture and loan capital and related to the externalities of research, development and innovation activity have been treated in other reports. We have also looked at the evidence concerning the role of incubators on innovation although we note that incubators are best seen as a diverse package of measures that constitute support to entrepreneurship and firms. As others have done, we have concluded that the impacts of incubators are difficult to assess systematically because of their heterogeneity.

In regard then to these two areas for entrepreneurship policy, we have attempted to locate and focus on evaluations that reported on additionality / net effect or that use methods of causal inference to determine the effectiveness and impacts of policy. Such studies tended to be found in the academic literature rather than amongst the reports on the performance of government schemes (that are publicly available). While policies and programmes for entrepreneurship can be simplistically modelled as a series of inputs beginning with cultural change followed by general and then more specific skill development, it is hard nevertheless to assess impact or trace causality because of the difficulty of defining discrete units of input, the presence of confounding factors and the length of time over which effects can build.

Overall, we find that recent policy initiatives in this area have not been evaluated. We have examined the literature and the literature covers schemes that have been evaluated around a decade ago. The policies and programmes that have emerged very recently have yet to be examined in detail. Thorough evaluation of the UK's coaching and accelerator programme (the Growth Accelerator which was known for a brief period as the Business Coaching for Growth Programme) using matched pair methods have not yet been carried out and until they are there is little evidence for us to consider.

\section{Cultural Change}

In regard to policies and programmes seeking to effect cultural and behavioural impacts, we believe that the literature can teach a number of lessons. Programmes that seek to increase awareness of entrepreneurship as a career choice can be seen within the area of education policy. However the growing interest in entrepreneurial education has not been matched by sound evaluation evidence. Part of the reason for this, as the OECD (2009) notes, is that the variability of objectives, content and delivery of such programmes do not facilitate reliable datagathering techniques. Thus not only have the evaluations undertaken varied greatly, the majority of these studies appear limited in that they fail to include a pre-test post-test method, and few employ control groups or have a longitudinal dimension.

The studies we have uncovered in this category have attempted to address one or more of these concerns and to understand whether or not entrepreneurship education causes individuals to change their intentions to become an entrepreneur. The effect of these schemes appears to be different at different points in of the education system: at school level, there is a negative and 
significant effect; at the college level the effect is low; at the university level, the effect is positive.

Two of these programmes noted the presence of an important effect on intentions, what we call a sorting effect, by which those who may be unsure about whether they wish to follow an entrepreneurial path will have their minds made up for them, often resulting in a decision not to become an entrepreneur. It almost goes without saying that these schemes which are aimed at cultural and behavioural change are not designed in the short term to impact upon production or efficiency of economic enterprises.

On a further point about the extent of awareness of entrepreneurship as a career and lifestyle choice and whether this has changed over the last decade: we have no evidence on this point either way, there are no evaluations that have considered this issue and this paper has been focused on evaluation of policy, but it is perhaps worth considering whether the market failure identified by Storey a decade ago is still as widespread now as it once was.

\section{Information and Advice - General and Specific}

Schemes to provide information and advice of a standardized form are closest in form to those which are addressed at the firm, rather than the entrepreneur. Schemes to promote information and advice are widespread. We note within our review two different forms of support. There is a form of support providing advice and information to early stage firms, and a form of support to nascent firms or pre-firms (pre start-up) where the recipient is the entrepreneur or would-be entrepreneur. Schemes of the former type are assessed by reference to the conventional economic impact categories, sales, employment and firm survival. Schemes of the latter type are assessed by reference to the outcomes for the recipient of the support, usually employment status (unemployed, employed (as an entrepreneur) and income.

Schemes of the former type are more homogenous in what they provide, while the latter kind are quite diverse and difficult to compare one against another. The former type of scheme, of which the Business Link scheme and the Swedish Innovation Centre are examples, show mixed results, with some schemes finding positive impacts in terms of sales, employment and survival while in others there were no significant impacts. The schemes offering support to pre start-up entrepreneurs again varied in outcome. In the short term, all schemes increased employment; however, in the longer term, the US scheme, GATE, does not show persistence of employment effects at 5 years, while the others do achieve this.

More specific and situational advice schemes provision is a further sub-category of schemes that seek to address the market failure for advice. The vast majority of programmes of this kind are targeted at those who have elected to run their own business. However, we have found one scheme (Oberschachtsiek and Scioch, 2011), that targets the unemployed, what could be called reluctant entrepreneurs. This scheme is really a combined scheme in that it provides both general training and more specific advice for the "would be" entrepreneur.

The scheme noted above (the German Bridging Allowance scheme) which combines both general and specific help to the unemployed is also one which has been evaluated in such a way as to provide an actual comparison. Some minor impacts are noted but the outcomes that have been observed are not a strong endorsement for this kind of scheme. 
Coaching schemes are difficult to assess for impact. Those schemes providing assistance to new entrepreneurs running their own business are popular with those who receive the coaching but there is a lack of studies that consider the counterfactual case. It is our belief that as more of these schemes are put into operation, and there is an expectation that they will be, more evaluation will take place. This may reveal the factors that affect success.

While we have found a trend towards entrepreneurial support, we have found no studies that follow up explicitly on the contrast between specific help and more general or operational support, in effect a comparison of two different forms of government assistance. It is a moot point therefore whether these schemes that do have different objectives should be subject to comparison. 


\section{References}

Amezcua, A. S. (2010). Boon or Boondoggle? Business Incubation as Entrepreneurship Policy. Unpublished manuscrupt, Martin J. Whitman School of Management.

Ardichvili, A., Cardozo, R., \& Sourav, R. (2003). "A theory of entrepreneurial opportunity identification and development." Journal of Business Venturing 10: 105-123.

Audretsch, D. B., I. Grilo, \& A. R. Thurik (2007). Explaining entrepreneurship and the role of policy: A Framework, in D. B. Audretsch, I. Grilo, \& A. R. Thurik (eds). Handbook of Research on Entrepreneurship Policy. Cheltanham: Edward Elgar, pp.1-17.

Barbero, J. L., J. C. Casillas, A. Ramos, \& S. Guitar (2012). "Revisiting incubation performance: How incubator typology affects results." Technological Forecasting and Social Change 79(5): 888-902.

Bergek, A. and C. Norrman (2008). "Incubator best practice: A framework." 28(1-2): 20-28.

Brockbank, A. (2008). "Is the coaching fit for purpose? A typology of coaching and learning approaches." Coaching: An International Journal of Theory, Research and Practice 1(2): $132-144$.

Caliendo, M. and S. Kunn (2011). "Start-up subsidies for the unemployed: Long-term evidence and effect heterogeneity." Journal of Public Economics 95(3-4): 311-331.

Centre for Strategy and Evaluation Services (2011). Final Evaluation of the Entrepreneurship and Innovation Programme Final Report.

Cooper, R. S., (2003). "Purpose and Performance of the Small Business Innovation Research (SBIR) Program." Small Business Economics 20(2): 137-151.

Cox, D. and J. Rigby, Eds. (2012). Innovation Policy Challenges for the 21st Century. Routledge Studies in Innovation, Organizations and Technology.

Dawson, C., A. Henley, \& P. Latreille (2009). Why Do Individuals Choose Self-Employment? IZA Discussion Paper No. 3974, Institute for the Study of Labor.

Dee, N. J., F. Livesey, D. Gill, \& T. Minshall (2011). Incubation for Growth: A review of the impact of business incubation on new ventures with high growth potential. NESTA.

Dee, N. J., D. Gill, R. Lacher, F. Livesey, \& T. Minshall (2012). A Review of Research on the Role and Effectiveness of Business Incubation for High-growth Start-ups. The Centre for Technology Management Working Paper. Cambridge, University of Cambridge.

Dess, G. G., B. C. Pinkham, \& H. Yang (2011). "Entrepreneurial Orientation: Assessing the Construct's Validity and Addressing Some of Its Implications for Research in the Areas of Family Business and Organizational Learning." Entrepreneurship Theory and Practice 35(5): 1077-1090.

East Midlands Development Agency (EMDA) (2005). High Growth Business Coaching Report.

Eckhardt, I. T., S. Shane, \& F. Delmar (2006). "Multistage selection and the financing of new ventures." Management Science 52(2): 220-232.

Ecorys (2012). EU SMEs in 2012: at the crossroads. Rotterdam.

EKOSGEN (2010). Evaluation of the North East Entrepreneurs Forum, Contract 208846.

Fairlie, R. W., D. Karlan, \& J. Zinman (2012). "Behind The Gate Experiment: Evidence On Effects Of And Rationales For Subsidized Entrepreneurship Training." NBER Working Paper Series Working Paper 17804.

Feldman, D. C. and M. J. Lankau (2005). "Executive coaching: A review and agenda for future research." Journal of Management 31(6): 829-848.

Fossen, F.M. and T.J.M. Büttner (2012). The Returns to Education for Opportunity Entrepreneurs, Necessity Entrepreneurs, and Paid Employees, IZA Discussion Paper No. 6819, Institute for the Study of Labor.

Gale, I., A. Liljenstrand, J. Pardieu, \& D.M. Nebeker (2002). Coaching: Who, what, where, when and how. Executive Summary of Coaching Practices.

Hawkins, P. (2008). "The coaching profession: some of the key challenges." Coaching: An International Journal of Theory, Research and Practice 1(1): 28 - 38.

Henrekson, M. and M. Stenkula (2009). Entrepreneurship and Public Policy. IFN Working Paper No. 804. 
IPREG (2011). Entrepreneurship and SME-policies across Europe: The cases of Sweden, Flanders, Austria and Poland.

Johansen, V., V. Schanke, \& T.H. Clausen (2012). Entrepreneurship Education and Pupils' Attitudes Towards Entrepreneurs, in T. Burger-Helmchen (ed.), Entrepreneurship Born, Made and Educated. Intechopen.com.

Kauffman Foundation (2012). "Start-Up Act for the States".

Kuiper, A. A. B. H. (2011). A Policy Theory Evaluation of the Dutch SME and Entrepreneurship Policy Program between 1982 and 2003. E. R. R. r. n. H201117.

Lambrecht, I. and F. Pirnay (2005). "An evaluation of public support measures for private external consultancies to SMEs in the Walloon Region of Belgium." Entrepreneurship \& Regional Development: An International Journal 17(2): 89-108.

Lange, J. E., E. Marram, et al. (2011). "Does an entrepreneurship education have lasting value? A study of careers of 4,000 alumni." Frontiers of Entrepreneurship Research 31(6 Article 2).

Larivière, M. (2007). Evaluation Report on Regional Export Promotion Organizations (ORPEXs). I. a. E. T. Economic Development.

Lepoutre, J., W. van den Berghe, O. Tilleuil, \& Crijns, H. (2010). "A new approach to testing the effects of entrepreneurship education among secondary school pupils." Vlerick Leuven Gent Working Paper Series 2010/01.

Lorz, M. (2011). The Impact of Entrepreneurship Education on Entrepreneurial Intention. School of Management, Economics, Law, Social Sciences and International Affairs, University of St. Gallen.

Marxt, C. and A. Piekkola (2007). Entrepreneurship awards as a source of national innovation capability: A case from Switzerland. Conference of the Portland International Center for Management of Engineering and Technology (PICMET 2007), Portland, OR, Picmet.

Mole, K., M. Hart, S. Roper, \& D. Saal (2008). "Differential gains from Business Link support and advice: a treatment effects approach." Environment and Planning C: Government and Policy 26: 315-334.

NESTA (2009a). "Measuring Business Growth."

NESTA (2009b). A review of mentoring literature and best practice.

NESTA (2009c). "The vital 6 per cent: How high-growth innovative businesses generate prosperity and jobs."

Nicolaou, N. and S. Shane (2009). "Can genetic factors influence the likelihood of engaging in entrepreneurial activity?" Journal of Business Venturing 24(1): 1-22.

Nicolaou, N., S. Shane, et al. (2008). "Is the tendency to engage in entrepreneurship genetic?" Management Science 54(1): 167-179.

Nicolaou, N., S. Shane, L. Cherkas, \& T.D. Spector (2009). "Opportunity recognition and the tendency to be an entrepreneur: A bivariate genetics perspective." Organizational Behavior and Human Decision Processes 110(2): 108-117.

Norrman, C. and L. Bager-Sjogren (2011). "Entrepreneurship policy to support new innovative ventures: Is it effective?" International Small Business Journal 28(6): 602-619.

Oberschachtsiek, D. and P. Scioch (2011). The outcome of coaching and training for selfemployment: A statistical evaluation of non-financial support schemes for unemployed business founders in Germany. IAB Discussion Paper.

OECD (2009). "Evaluation of Programmes Concerning Education for Entrepreneurship." Report by the OECD Working Party on SMEs and Entrepreneurship, OECD.

OECD (2010). "Entrepreneurship Skills", in SMEs, Entrepreneurship and Innovation.

Oosterbeek, H., M. van Praag, \& A. Ijsselstein (2010). The Impact of Entrepreneurship Education on Entrepreneurship Competencies and Intentions: An Evaluation of the Junior Achievement Student Mini-Company Program. European Economic Review. 54 442-454.

Peterson, D. B., and Hicks, M.D. (1995). The leader as coach: Strategies for coaching and developing others. Minneapolis, Minnesota, Personnel Decisions.

Roper, S. and M. Hart (2005). "Small Firm Growth And Public Policy In The UK: What Exactly are the Connections?" Working Paper, Aston Business School RP0504. 
Rotger, G. P., M. Gørtzb, \& D. Storey (2012). "Assessing the effectiveness of guided preparation for new venture creation and performance: Theory and practice." Journal of Business Venturing 27(4): 506-521.

Schwartz, M. (2012). "A control group study of incubators' impact to promote firm survival." Journal of Technology Transfer(DOI:10.1007/s10961-012-9254-y).

Shane, S. (2009). "Why encouraging more people to become entrepreneurs is bad public policy." Small Business Economics 33(2): 141-149.

Shane, S. (2012). "Reflections on the 2010 AMR Decade Award: Delivering on the Promise of Entrepreneurship as a field of research." Academy of Management Review 37(1): 10-20.

Shane, S., N. Nicolaou, et al. (2010). "Genetics, the Big Five, and the Tendency to Be SelfEmployed." Journal of Applied Psychology 95(6): 1154-1162.

Shane, S. and S. Venkataraman (2000). "The promise of entrepreneurship as a field of research." Academy of Management Review 25(1): 217-226.

Slavtchev, V., S. Laspita, \& H. Patzelt (2012). "Effects of entrepreneurship education at universities." Jena Economic Research Papers 2012 - 025.

Stober, D. R. (2008). "Making it stick: coaching as a tool for organizational change." Coaching: An International Journal of Theory, Research and Practice 1(1): 71 - 80.

Storey, D. I. (2005). "Entrepreneurship, Small and Medium Sized Enterprises and Public Policies", in Z.J. Acs and D.B. Audretsch (eds.), Handbook of Entrepreneurship Research: 473-511.

Tamasy, C. (2007). "Rethinking Technology-Oriented Business Incubators: Developing a Robust Policy Instrument for Entrepreneurship, Innovation, and Regional Development?" Growth and Change 38(3): 460-473.

Tavoletti, E. (2012). "Business Incubators: Effective Infrastructures or Waste of Public Money? Looking for a Theoretical Framework, Guidelines and Criteria." Journal of the Knowledge Economy(DOI 10.1007/s13132-012-0090-y).

Turok, I. and M. Raco (2000). "Developing expertise in small and medium-sized enterprises: an evaluation of consultancy support." Environment and Planning C: Government and Policy 18(4): 409-427.

von Graevenitz, G., D. Harhoff, \& R. Weber (2010). "The effects of entrepreneurship education." Journal of Economic Behavior \& Organization 76: 90-112.

Weber, M. (1905). The Protestant Ethic and the Spirit of Capitalism.

Wren, C. and D. J. Storey (2002). "Evaluating the effect of soft business support upon small firm performance." Oxford Economic Papers 54(2): 334-365.

Wycherley, I. M. and E. Cox (2008). "Factors in the selection and matching of executive coaches in organisations." Coaching: An International Journal of Theory, Research and Practice 1(1): $39-53$. 


\section{Annex 1 List of Measures}

\begin{tabular}{|c|c|c|c|c|c|c|}
\hline $\begin{array}{l}\text { Country/ } \\
\text { Region }\end{array}$ & Measure & Study & Period & $\begin{array}{l}\text { Evaluation } \\
\text { Method }\end{array}$ & $\begin{array}{l}\text { Outcome } \\
\text { Variables }\end{array}$ & Impacts \\
\hline $\begin{array}{l}\text { Belgium } \\
\text { (Wallonia) }\end{array}$ & $\begin{array}{l}\text { Public support } \\
\text { measure for } \\
\text { private external } \\
\text { consultancies to } \\
\text { SMEs }\end{array}$ & $\frac{\text { Lambrecht and }}{\text { Pirnay (2005) }}$ & $\begin{array}{l}1997- \\
2001\end{array}$ & $\begin{array}{l}\text { General } \\
\text { review - } \\
\text { monitoring } \\
\text { level }\end{array}$ & & $\begin{array}{l}\text { Need to orient } \\
\text { service to needs } \\
\text { of entrepreneur } \\
\text { (neo-Austrian } \\
\text { understanding of } \\
\text { entrepreneur); } \\
\text { confusion in } \\
\text { public policy } \\
\text { offerings; some } \\
\text { self reported } \\
\text { additionality } \\
\text { from the scheme. }\end{array}$ \\
\hline Canada & $\begin{array}{l}\text { Regional Export } \\
\text { Promotion } \\
\text { Organizations } \\
\text { offering of } \\
\text { business } \\
\text { coaching }\end{array}$ & Larivière (2007) & $\begin{array}{l}2004- \\
2006\end{array}$ & Monitoring & & $\begin{array}{l}\text { Suggests correct } \\
\text { targeting i.e. } \\
\text { demand but no } \\
\text { control group } \\
\text { used }\end{array}$ \\
\hline Canada & OPREX & Lariviere (2007) & & $\begin{array}{l}\text { Statistical } \\
\text { Monitoring }\end{array}$ & & \\
\hline Denmark & $\begin{array}{l}\text { North Jutland } \\
\text { Entrepreneurial } \\
\text { Network }\end{array}$ & $\frac{\text { Rotger et al. }}{(2012)}$ & $\begin{array}{l}2002- \\
2005\end{array}$ & PSM; DiD & $\begin{array}{l}\text { Survival } \\
\text { Employment } \\
\text { Output }\end{array}$ & $\begin{array}{l}\text { +ve } \\
\text { +ve } \\
\text { +ve }\end{array}$ \\
\hline Germany & $\begin{array}{l}\text { Entrep Uni } \\
\text { Course }\end{array}$ & $\begin{array}{l}\text { von Graevenitz } \\
\text { et al. (2010) }\end{array}$ & $\begin{array}{l}2008- \\
2009\end{array}$ & $\begin{array}{l}\text { Bayesian } \\
\text { Updating } \\
\text { Model; OLS }\end{array}$ & $\begin{array}{l}\text { Entrep. } \\
\text { Intent }\end{array}$ & $+\mathrm{ve}$ \\
\hline Germany & $\begin{array}{l}\text { Start-up subsidy; } \\
\text { bridging } \\
\text { allowance }\end{array}$ & $\begin{array}{l}\text { Caliendo and } \\
\text { Kunn (2011) }\end{array}$ & $\begin{array}{l}2003- \\
2008\end{array}$ & PSM; DiD & $\begin{array}{l}\text { Not Unempl } \\
\text { In paid/Self } \\
\text { Emp } \\
\text { Pers Income }\end{array}$ & $\begin{array}{l}\text { +ve } \\
+\mathrm{ve} \\
+\mathrm{ve}\end{array}$ \\
\hline Germany & $\begin{array}{l}\text { Bridging } \\
\text { allowance } \\
\text { supplementary }\end{array}$ & $\begin{array}{l}\text { Oberschachtsiek } \\
\text { and Scioch } \\
\underline{(2011)}\end{array}$ & & PSM; DiD & $\begin{array}{l}\text { Training: } \\
\text { Exit Emp } \\
\text { Exit } \\
\text { Unemp } \\
\text { Coaching: } \\
\text { Exit Emp } \\
\text { Exit } \\
\text { Unemp }\end{array}$ & $\begin{array}{l}\text { n.s. } \\
\text {-ve } \\
\text {-ve } \\
\text { n.s. }\end{array}$ \\
\hline EU & $\begin{array}{l}\text { Competitiveness } \\
\text { and Innovation } \\
\text { Programme: } \\
\text { Parts E and F }\end{array}$ & $\begin{array}{l}\text { Centre for } \\
\text { Strategy and } \\
\text { Evaluation } \\
\text { Services (2011) } \\
\end{array}$ & $\begin{array}{l}2007- \\
2011\end{array}$ & $\begin{array}{l}\text { Survey and } \\
\text { Monitoring }\end{array}$ & $\begin{array}{l}\text { Relevance } \\
\text { Efficiency } \\
\text { Effectiveness }\end{array}$ & $\begin{array}{l}\text { Programme. } \\
\text { coherent - meets } \\
\text { needs } \\
\text { Desired effects } \\
\text { being achieved } \\
\text { Effective but } \\
\text { active } \\
\text { management of } \\
\text { cross cutting } \\
\text { activities needed }\end{array}$ \\
\hline Scotland & $\begin{array}{l}\text { Expert Help } \\
\text { Scheme }\end{array}$ & $\begin{array}{l}\text { Turok and Raco } \\
(2000)\end{array}$ & $\begin{array}{l}1988- \\
1994\end{array}$ & $\begin{array}{l}\text { Review and } \\
\text { monitoring } \\
\text { based on } \\
\text { self- } \\
\text { reporting }\end{array}$ & & $\begin{array}{l}\text { Support offerings } \\
\text { too simplistic to } \\
\text { be effective; } \\
\text { strong focus on } \\
\text { competitiveness } \\
\text { as part of the } \\
\text { Consultancy } \\
\text { Initiative (CI) }\end{array}$ \\
\hline
\end{tabular}




\begin{tabular}{|c|c|c|c|c|c|c|}
\hline Sweden & $\begin{array}{l}\text { Swedish } \\
\text { Innovation } \\
\text { Centre }\end{array}$ & $\begin{array}{l}\text { Norrman and } \\
\text { Bager-Sjogren } \\
\text { (2011) }\end{array}$ & $\begin{array}{l}1994- \\
2003\end{array}$ & Match pairs & $\begin{array}{l}\text { Commercial. } \\
\text { Sales } \\
\text { Assets } \\
\text { Employees }\end{array}$ & \\
\hline $\begin{array}{l}\text { Sweden, } \\
\text { Flanders, } \\
\text { Austria, and } \\
\text { Poland }\end{array}$ & $\begin{array}{l}\text { Review of } \\
\text { entrepreneurship } \\
\text { programmes }\end{array}$ & IPREG (2011) & $\begin{array}{l}\text { Reported } \\
2011\end{array}$ & $\begin{array}{l}\text { General } \\
\text { review: } \\
\text { measures } \\
\text { and } \\
\text { programme } \\
\text { design }\end{array}$ & & $\begin{array}{l}\text { Importance of } \\
\text { coherence of } \\
\text { measures, also } \\
\text { need to segment } \\
\text { support } \\
\text { offerings; private } \\
\text { sector } \\
\text { counselling } \\
\text { quality needs } \\
\text { monitoring } \\
\text { (Flanders); } \\
\text { Austrian policy } \\
\text { felt to be } \\
\text { confusing and } \\
\text { possibly } \\
\text { redundant }\end{array}$ \\
\hline Switzerland & $\begin{array}{l}\text { Business Plan } \\
\text { Contest } \\
\text { (Privately } \\
\text { funded) }\end{array}$ & $\begin{array}{l}\text { Marxt and } \\
\text { Piekkola (2007) }\end{array}$ & $\begin{array}{l}1998- \\
2006\end{array}$ & $\begin{array}{l}\text { Monitoring } \\
\text { and self- } \\
\text { evaluation }\end{array}$ & $\begin{array}{l}\text { Start up } \\
\text { readiness }\end{array}$ & $\begin{array}{l}\text { Increases start } \\
\text { up readiness, } \\
\text { places } \\
\text { competitors } \\
\text { within firms, } \\
\text { existing business } \\
\text { networks and } \\
\text { gives access to } \\
\text { existing } \\
\text { successful } \\
\text { entrepreneurs, } \\
\text { competition is } \\
\text { oriented towards } \\
\text { marketable } \\
\text { product } \\
\text { process } \\
\text { innovations }\end{array}$ \\
\hline Netherlands & $\begin{array}{l}\text { Dutch SME and } \\
\text { Entrepreneurship } \\
\text { Policy Program }\end{array}$ & Kuiper (2011) & $\begin{array}{l}1982- \\
2003\end{array}$ & Monitoring & & $\begin{array}{l}\text { Combi-scheme } \\
\text { with financial } \\
\text { assistance }\end{array}$ \\
\hline Netherlands & $\begin{array}{l}\text { Student Mini- } \\
\text { company Scheme }\end{array}$ & Oosterbeek et al. & $\begin{array}{l}2005- \\
2006\end{array}$ & IV; DiD & $\begin{array}{l}\text { Entrep. } \\
\text { Intent }\end{array}$ & -ve \\
\hline New Zealand & $\begin{array}{l}\text { Entrep. Uni } \\
\text { Course }\end{array}$ & $\begin{array}{l}\text { Slavtchev et al. } \\
\text { (2012) }\end{array}$ & $\begin{array}{l}2006- \\
2008\end{array}$ & DiD & $\begin{array}{l}\text { Entrep. } \\
\text { Intent }\end{array}$ & -ve \\
\hline OECD Reviews & $\begin{array}{l}\text { Examples } \\
\text { reviewed of } \\
\text { government } \\
\text { support for } \\
\text { entrepreneurship } \\
\text { within firms, } \\
\text { within schools, } \\
\text { the university } \\
\text { system and } \\
\text { through } \\
\text { vocational } \\
\text { education (VET) } \\
\text { institutions }\end{array}$ & $\underline{\text { OECD (2010) }}$ & & $\begin{array}{l}\text { Reviews / } \\
\text { qualitative } \\
\text { evaluation; } \\
\text { not } \\
\text { measuring } \\
\text { additionality } \\
\text { and net } \\
\text { effects }\end{array}$ & & $\begin{array}{l}\text { Attempts } \\
\text { definition of } \\
\text { entrepreneurship } \\
\text { as convergent } \\
\text { skill set akin to } \\
\text { green business } \\
\text { skills }\end{array}$ \\
\hline UK & $\begin{array}{l}\text { Consultancy } \\
\text { Initiative }\end{array}$ & $\begin{array}{l}\text { Wren and Storey } \\
(2002)\end{array}$ & $\begin{array}{l}1988- \\
1996\end{array}$ & $\begin{array}{l}\text { Two stage } \\
\text { probit }\end{array}$ & $\begin{array}{l}\text { Survival } \\
\text { Turnover } \\
\text { Employment }\end{array}$ & $\begin{array}{l}\text { +ve(med) } \\
\text { +ve } \\
\text { +ve }\end{array}$ \\
\hline UK & Business Link & $\begin{array}{l}\text { Roper and Hart } \\
(2005)\end{array}$ & $\begin{array}{l}1996- \\
1998\end{array}$ & IV & $\begin{array}{l}\text { Sales } \\
\text { Employment }\end{array}$ & $\begin{array}{l}\text { n.e. } \\
\text { n.e. }\end{array}$ \\
\hline
\end{tabular}




\begin{tabular}{|c|c|c|c|c|c|c|}
\hline & & & & & Productivity & n.e. \\
\hline UK & Business Link & $\begin{array}{l}\text { Mole et al. } \\
\text { (2008) }\end{array}$ & 2003 & DiD; Probit & $\begin{array}{l}\text { Participation } \\
\text { Employment } \\
\text { Sales }\end{array}$ & $\begin{array}{l}\text { +ve (young) } \\
\text { +ve } \\
\text {-ve }\end{array}$ \\
\hline US & $\begin{array}{l}\text { Growing America } \\
\text { through } \\
\text { Entrepreneurship }\end{array}$ & $\frac{\text { Fairlie et al. }}{(2012)}$ & & RCT & $\begin{array}{l}\text { Ownership } \\
\text { Employment }\end{array}$ & $\begin{array}{l}\text { +ve (SR) } \\
\text { +ve (SR) }\end{array}$ \\
\hline US & SBIR & Cooper (2003) & & Review & & $\begin{array}{l}\text { SBIR has } \\
\text { demonstration } \\
\text { effect }\end{array}$ \\
\hline World-Wide & $\begin{array}{l}\text { Review of } \\
\text { coaching } \\
\text { schemes }\end{array}$ & NESTA (2009b) & N.A. & $\begin{array}{l}\text { Literature } \\
\text { Review }\end{array}$ & & $\begin{array}{l}\text { Lessons on } \\
\text { effectiveness of } \\
\text { coaching, puts } \\
\text { forward key } \\
\text { success factors }\end{array}$ \\
\hline
\end{tabular}

\section{Notes:}

IV=instrumental variables $\mathrm{DiD}=$ difference in difference PSM=Propensity Score Matching RCT=randomised controlled trial Med $=$ medium term effect $\mathrm{SR}=$ short run effect 


\section{Manchester Institute of Innovation Research}

The Manchester Institute of Innovation Research (MloIR) is the research centre of excellence in the Manchester Business School (MBS) and The University of Manchester in the field of innovation and science studies. With more than 50 full members and a range of associated academics from across the University, MloIR is Europe's largest and one of the World's leading research centres in this field.

The Institute's key strengths lie in the linkage and cross-fertilisation of economics, management and policy around innovation and science. Building on forty years of tradition in innovation and science studies, the Institute's philosophy is to combine academic rigour with concrete practical relevance for policy and management. This includes broad engagement with and research for policy makers and societal and industrial stakeholders in the Manchester City Region, across the UK and internationally. MloIR is also firmly committed to a range of teaching activities within and beyond MBS and integrates a strong and successful PhD programme into its research activities. The Institute has a visitor programme for academics and management and policy practitioners and provides a range of popular and high level executive education courses on evaluation, foresight and S\&T Policy. 